DEMOGRAPHIC RESEARCH

VOLUME 37, ARTICLE 20, PAGES 635-668 PUBLISHED 12 SEPTEMBER 2017

http://www.demographic-research.org/Volumes/Vol37/20/

DOI: 10.4054/DemRes.2017.37.20

Research Article

\title{
The effect of the Great Recession on permanent childlessness in Italy
}

\section{Marcantonio Caltabiano}

\section{Chiara Ludovica Comolli}

\section{Alessandro Rosina}

(C) 2017 Caltabiano, Comolli \& Rosina.

This open-access work is published under the terms of the Creative Commons Attribution NonCommercial License 2.0 Germany, which permits use, reproduction, and distribution in any medium for noncommercial purposes, provided the original author(s) and source are given credit. See http://creativecommons.org/licenses/by-nc/2.0/de/ 


\section{Contents}

1 Introduction $\quad 636$

$2 \quad$ Fertility and the business cycle 639

3 Trends in fertility and childlessness in Italy 640

$4 \quad$ Data and methods $\quad 643$

$5 \quad$ Results $\quad 648$

$\begin{array}{lll}5.1 & \text { Descriptive results } & 648\end{array}$

$\begin{array}{lll}5.2 & \text { Difference-in-difference regression results } & 651\end{array}$

6 Discussion 654

$7 \quad$ Acknowledgements $\quad 657$

$\begin{array}{ll}\text { References } & 658\end{array}$

$\begin{array}{ll}\text { Appendix } & 663\end{array}$ 


\title{
The effect of the Great Recession on permanent childlessness in Italy
}

\author{
Marcantonio Caltabiano ${ }^{1}$ \\ Chiara Ludovica Comolli ${ }^{2}$ \\ Alessandro Rosina ${ }^{3}$
}

\begin{abstract}
BACKGROUND

The Great Recession had a strong effect not only on the economy of developed countries but also on family dynamics. Many studies investigate how the crisis affected fertility behavior, but the link between economic shocks and childbearing is still debated.
\end{abstract}

\section{OBJECTIVE}

Most studies argue that fertility responds to recessions with only a temporary postponement of first births by young women. A paper by Comolli and Bernardi (2015), though, finds a permanent positive effect of the Great Recession in the United States on childlessness among women in their late thirties. In light of these results, we test whether a similar effect is found in a different context, i.e., Italy.

\section{METHODS}

We apply the difference-in-difference method to synthetic cohorts of Italian childless women in their late thirties to assess whether the crisis had a permanent impact on the cohorts' childlessness rates. We use the Istat 2004-2013 Italian Labor Force Survey (LFS).

\section{RESULTS}

During the Great Recession in Italy, contrary to the United States, childlessness among women around the age of 40 registered short-term negative fluctuations. Only mideducated women seem to have slightly postponed first births during the crisis.

\section{CONTRIBUTION}

This paper contributes to the debate on how economic shocks affect fertility, with the objective of assessing whether the recent Great Recession had a permanent effect on

\footnotetext{
${ }^{1}$ Università di Messina, Messina, Italy. E-Mail: caltabiano@unime.it

${ }^{2}$ Stockholm University, Stockholm, Sweden.

${ }^{3}$ Università Cattolica del Sacro Cuore, Laboratorio di statistica applicata alle decisioni economico-aziendali, Milan, Italy.
} 
childlessness in Italy. The main conclusion is that, except for the group of women with average education, the crisis did not increase permanent childlessness among Italian women beyond its preexisting positive long-term trend.

\section{Introduction}

Permanent childlessness in Europe is on the rise, not only in northern and continental European countries but also in southern - and more traditional - countries like Italy, where an increasing number of women are forgoing motherhood (Gonzáles and JuradoGuerrero 2006; Miettinen et al. 2015; Mills et al. 2015; Sobotka 2017).

Childlessness among Italian women at the age of 45 increased from about $12 \%$ for the birth cohort of 1950 to almost $25 \%$ for the birth cohort of 1980 (authors' estimates on the Human Fertility Database, Eurostat, and Istat data). Notwithstanding this very rapid diffusion of permanent childlessness, research on this topic is relatively rare in Italy where, until recently, it appeared to be due only to celibacy or biological sterility (Tanturri and Mencarini 2008). However, investigating the determinants of childlessness in Italy is crucial because the postponement of first births reduces completed fertility in a society that already faces the challenge of a rapidly aging population and an increasing dependency ratio, dramatically driven up by this long-term decline in births (Billari and Kohler 2004; Lesthaeghe and Willems 1999; Mynarska et al. 2015; Sobotka 2004).

The diversification of living arrangements and of the life-course, and the weakening of the social norm of parenthood might be responsible both for the decline in family size and for the diffusion of childlessness. Other structural conditions incentivizing postponement are the increase in the direct and indirect costs of childbearing (especially for women), the lack of adequate family policies and childcare facilities, and the gender-unequal division of domestic tasks within the couple. Finally, yet importantly, employment insecurity and financial uncertainty have been proved to delay family formation. The severe recession that has hit advanced economies since the summer of 2007 had a significant effect not only on the economic system but also on family dynamics and family formation. In particular, the preexisting long-term declining trend in marriage rates has accelerated since 2008, and the increase in fertility registered during the 2000s has abruptly halted, and in some cases even reverted. These trends are common to most countries in Europe and the United States.

During the first phase of the Great Recession, Italy, has been in an economic dip for a longer period compared to other countries, and the negative growth registered in the GDP has also been stronger. In the second phase, when the financial crisis turned 
into a European sovereign debt crisis, Italy again entered into recession in the third quarter of 2011 and continued to experience significantly negative economic growth for the whole of 2013 (OECD 2017). The crisis generated tremendous consequences, in particular for the Italian labor market: Between 2008 and 2013, almost a million jobs were lost, and the unemployment rate went from $6.8 \%$ to $12.2 \%$ (Eurostat 2017; Istat 2017). ${ }^{4}$ Also, after the peak of the crisis, the growth of the Italian economy has remained feeble at most, lower than all other major European states. Only in 2016 has the GDP again reached the level of the year 2000, but it is still far from its historical maximum (Istat 2017).

Many studies address the issue of how the business cycles affect fertility behavior (e.g., Adserà 2004, 2011; Currie and Schwandt 2014; Del Bono, Weber, and WinterEbmer 2015; Fokkema et al. 2008; Inanc 2015; Kreyenfeld and Andersson 2014; Meron and Widmer 2002; Morgan, Cumberworth, and Wimer 2011; Sobotka, Skirbekk, and Philipov 2010, 2011), and most of the findings indicate that fertility slows down during recession and accelerates during economic booms. During economic downturns, individuals delay family commitments such as marriage and childbearing. Many of these studies document the postponement of childbearing during periods of economic recession, especially for couples at low parities (first births) and among younger women (Goldstein et al. 2013; Schneider 2015). Postponement is usually only temporary and, as soon as the economy recovers, couples recuperate marriages and births, at least in part. The literature is rich, but few studies address the permanent demographic effects of the crisis, and even fewer consider the consequences of economic crises specifically for childlessness rates (Comolli and Bernardi 2015). Although most of the existing literature shows that the recession has no impact on childbearing at older ages (Goldstein et al. 2013; Schneider 2015), other results for the United States show instead a slight increase in permanent childlessness due to the Great Recession (Comolli and Bernardi 2015).

The present paper aims at filling these gaps in the literature (a) by testing the existence of a link between the recent economic dip and childlessness rates in Italy and (b) by investigating whether the Great Recession had a permanent effect on fertility in terms of forgone (first) births. To do so, we focus on a specific group of Italian women, namely childless women in their late thirties who spent the last years of their reproductive lives during the Great Recession and, during this extremely uncertain period, had to decide whether to have their first child or postpone childbearing (McDonald et al. 2011). For this particular group of women, clearly, the chances of successfully postponing childbearing are lower because they are approaching the limit of their biological ability to conceive. We argue therefore that, should these women

\footnotetext{
${ }^{4}$ The unemployment rate was particularly high among young adults: $23 \%$ among those $15-34$ years old and $40 \%$ among those 15-24 years old (Eurostat 2017; Istat 2017).
} 
postpone motherhood due to the crisis, few of them would be able to recuperate births after the recession, and thus most of these postponed births would be lost.

On the one hand, we might think that there are no reasons that the uncertainty generated by the Great Recession would have a different effect on the childbearing decisions of older women compared to the decisions of younger women. We might argue that economic insecurity has different effects on the reproductive decisions of childless women compared to mothers, or of women with different educational levels, or of women who belong to different social classes. We might think that there is no difference in the impact of the crisis on women in their early reproductive years compared to women in their late thirties. However, women who are close to the age of 40 know that their chances to conceive a baby decrease every year, and they might not be willing to take the risk of postponing motherhood due to financial and labor market uncertainty. The results of studies in the United States (Comolli and Bernardi 2015) confirm that a non-negligible number of white American women took that risk during the crisis.

As will be presented later in more detail, outcomes in Italy are strongly dissimilar to the American outcomes, which makes the comparison interesting. First, despite the large share of women who remain without children, an increasing prevalence of childlessness is a recent phenomenon in Italy compared to the United States. Tanturri and Mencarini (2008: 53) point out that "a cross-country comparison of the prevalence of childlessness points up the uniqueness of the Italian pattern and its rapid change," and Miettinen et al. (2015) show that Italy, among western countries, is unique in the speed of change in rates of childlessness. This increase in childlessness is also predicted to continue in the future for women in the 1970s and 1980s cohorts (Sobotka 2017). When studying the determinants of childlessness, Italy thus represents a particularly interesting case. ${ }^{5}$

Second, despite registering one of the smallest number of children per woman among western countries, one of the highest ages at first child, and a large share of childless women (Adserà 2004; Del Boca 2002; Balbo, Billari, and Mills 2013; Caltabiano 2016), in Italy the social norm of motherhood is still quite strong. Also, economic circumstances may not be as powerful as the cultural and social norm of childbearing (Micheli 2000, 2012). ${ }^{6}$

\footnotetext{
${ }^{5}$ In addition, the design applied in our paper facilitates analyses in contexts where high quality longitudinal data is not available. Italy is one of these cases for which it is difficult to get recent longitudinal data covering the crisis period that is necessary to investigate childbearing behavior and its socioeconomic determinants.

${ }^{6}$ The Italian institutional context is also different from that of the United States in terms of redistributive and broad welfare policies. However, in terms of family policies and financial support to parents, in Italy it is also difficult and costly to have babies. While young parents might be able to rely on extended family, the older the parents get, the less support they might receive from grandparents.
} 
These are some of the reasons why we might expect to find a postponement effect of the crisis on first births to Italian women in their early thirties, but a much smaller effect (or none) as women get close to the age of 40 , even in the presence of the massive economic and labor market uncertainty generated by the Great Recession.

Section 2 of this paper presents the recent evidence on the effects of economic crises on fertility. Section 3 illustrates the recent trends in fertility and childlessness in the Italian context and presents the research questions of the paper. Section 4 describes the data and the method we use in the analyses. Section 5 illustrates the results of these analyses, and Section 6 discusses conclusions.

\section{Fertility and the business cycle}

A growing number of studies address the issue of how business cycles affect childbearing behavior (Adserà 2004, 2011; Comolli and Bernardi 2015; Currie and Schwandt 2014; Del Bono, Weber, and Winter-Ebmer 2015; Fokkema et al. 2008; Inanc 2015; Kreyenfeld and Andersson 2014; Meron and Widmer 2002; Morgan, Cumberworth, and Wimer 2011; Sobotka, Skirbekk, and Philipov 2010, 2011). Many of these studies document the negative effect of economic downturns on births in Europe and in the United States, showing postponement of childbearing during economic recessions, especially among women at younger ages (Goldstein et al. 2013) and at low parities. The procyclical association between the business cycle and fertility is established by looking at period trends or specific macroeconomic indicators such as GDP, unemployment, consumer confidence, or housing market characteristics (Comolli 2017; Kreyenfeld, Andersson, and Pailhé 2012; Schneider 2015; Sobotka, Skirbekk, and Philipov 2010, 2011).

Most of the evidence regarding Italy assesses the link between uncertainty in the labor market and childbearing behavior. One of the main theoretical arguments driving the postponement of childbearing during economic dips relates labor market constraints - such as rising unemployment and declining wages - to the rise in the relative cost of childbearing and thus to the growing incentives for childlessness. In an increasingly uncertain social and economic context, some couples might consider a long-term commitment to parenthood unsustainable.

Cazzola, Pasquini, and Angeli (2016) investigate the relationship between unemployment and fertility in Italy in the period 1995-2012, focusing on the geographical differences in this correlation. The recent increase in male and female unemployment rates seems to be negatively linked to fertility in the northern and central areas of Italy, but the results for the southern regions are ambiguous. The weak and positive relationship emerging between unemployment and fertility rates in the south 
could mean that couples take advantage of periods out of the labor market to have children. However, the authors suggest that results could have been affected by the uncertainty in the local labor market participation data, which does not take into account the undeclared work occurring in the black economy. ${ }^{7}$ Santarelli (2011) and Vignoli, Drefahl, and De Santis (2012) analyze the labor force status of married couples in Italy and their effect on childbearing. The authors find higher first birth rates for couples with nonworking women, confirming the importance of the man's economic position on the decision of having a first child. González and Jurado-Guerrero (2006), who analyze the transition to motherhood, and Baizán (2005), who analyzes second or higher-order birth rates, find similar results.

In traditional countries like Italy, two distinct childbearing patterns can be observed: In the first group are couples in which the traditional male breadwinner model is in place. Women are full-time mothers (the so-called 'stay-at-home-moms'), do not participate in the labor market, and have children earlier. In the second group are couples in which both partners are highly educated, have higher income, and thus can afford to have children even though the mother is working (Testa, Cavalli, and Rosina 2014). For the scope of this paper, it would be interesting to know how much these couples suffered from labor market and financial insecurity during the crisis and whether they changed their childbearing behavior in response to that. However, at the time of writing we could not find any empirical evidence linking more directly the Great Recession to fertility behavior in Italy. In the next section, we illustrate the recent trends and specificities of the Italian context in fertility rates and childlessness.

\section{Trends in fertility and childlessness in Italy}

Despite strong family attachments and the prevalence of traditional family forms, persistently low fertility levels have long characterized Italy. After the baby boom in the mid-1960s, the total fertility rate (TFR) steadily declined to very low levels in the mid1980 s, reaching lowest-low fertility rates (less than 1.3 children per woman) in the period 1993-2003 (Caltabiano 2008). ${ }^{8}$ At the end of the nineties, fertility started to increase again, and TFR peaked in 2010 at 1.46. This increase was due to the recuperation of postponed births during the nineties (Caltabiano, Castiglioni, and Rosina 2009; Caltabiano 2016) but also to the larger share of births among immigrant women.

\footnotetext{
${ }^{7}$ In 2012, the incidence of black economy activity in the southern regions was estimated to reach $20.9 \%$ of total employment, compared with $12.1 \%$ in Italy as a whole (European Commission 2014).

${ }^{8}$ The long-term decline in fertility in Italy during the last three decades touched its lowest point in 1995, with a fertility rate of 1.19 children per woman.
} 
With the onset of the financial crisis, between 2008 and 2009, Italian births decreased by $1.4 \%$, and since then the decrease has further accelerated: Between 2009 and 2012, the number of births fell by $6.2 \%$. TFR in Italy declined uninterruptedly after 2010, reaching 1.34 in 2016, back to the level of 2004 (Istat 2017). If we look at agespecific births rates in Italy during the years of the crisis, we witness, as in other countries, that the largest fertility drop is concentrated among young women $(-9 \%$ in births for women who were younger than 25 between 2008 and 2012). For first births, this decline is even stronger $(-13.4 \%$ in births for women under 25$)$, while births among older women are still rising $(+7.4 \%$ for those $35-39$ years old, and $+26.9 \%$ for those 40+ years old between 2008 and 2012) (Istat 2017). Thus it seems that the negative fertility response to the recession in Italy is concentrated on women who can afford to postpone births because they are far from the biological limit of fertility (De Rose and Strozza 2015). ${ }^{9}$

The latter figures suggest that, if the biological limits of fertility are approaching, women do not change their reproductive behavior based on economic circumstances, in contrast to younger women who can afford to postpone their first child. However, the same results were found and the same conclusions were drawn for the United States, and yet, the most recent empirical evidence has shown that there has been a negative effect of the crisis on older women close to the end of their reproductive life (Comolli and Bernardi 2015). In this paper, we test whether the same happened in Italy, namely if women close to the end of their reproductive lives changed their fertility behavior, postponing their first child due to the crisis as women in their early thirties seem to be doing. (However, dissimilar to the younger women, the older women likely chose to definitively renounce motherhood.)

Another important issue to consider about the Italian context is the regional heterogeneity. Not only were the effects of the Great Recession different across regions (with the largest negative consequences registered in the south), but even fertility rates and the trends in the last decades are very different across the country. Traditionally, childbearing rates have been higher in the south of Italy compared to the north, but between the 1990s and the precrisis period, fertility rates were declining in the south and strongly increasing in the center and north of Italy. Regional fertility rates that were once very different converged in 2006/2007, and since then we witnessed a reversal of the geographical trends in fertility, with permanently higher rates in the north. ${ }^{10}$

The overall level of childlessness in Italy is also made up of heterogeneous regional trends (Caltabiano 2008). Until recently, overall fertility was higher in the

\footnotetext{
${ }^{9}$ The same is evident for the second parity: Among mothers who declared that they were affected by the recession, a smaller percentage of $40+$ women declared that they postponed a second child.

${ }^{10}$ Considering first births, the same geographical reversal appears: In the mid-1990s, first birth rates were higher in the south compared to the north, while two decades later the opposite was true.
} 
south, but women who remained unmarried and childless were also more common in the southern regions. In the north, overall fertility was lower, but childlessness was less common (Tanturri and Mencarini 2008). However, the situation has recently reversed: While the trend in childlessness in the south is more or less flat, the rate of childlessness is increasing rapidly in the north and in central Italy. These patterns indicate that the causes of childlessness have probably changed over time.

Another interesting and related issue is the educational gradient of fertility and childlessness in Italy. Traditionally negative, when studied comparatively to other countries and in an aggregate perspective (Wood, Neels, and Kil 2014), this gradient recently showed signs of a reversal at the individual level, at least in the northern regions (Caltabiano, Castiglioni, and Rosina 2009). There, more educated women still tend to enter motherhood later, compared to the lower educated, but they are more likely to recuperate births after age 30-35.

Studying paths to childlessness in Italy (and Poland), Mynarska et al. (2015) identified the largest majority of Italian childless women (more than $40 \%$ ) as working single women. However, the second largest category of childless women is composed of disadvantaged women who are very low educated, come from economically poor conditions, and have been unemployed and single for much of their adult lives (more than $20 \%$ ).

The distinction between voluntary (childfree) and involuntary childlessness is not clear-cut. Many women change their opinion over time or move back and forth from one position to the other. Many women delay pregnancy to the point that it becomes unlikely or impossible, in which case voluntary postponement is transformed into involuntary childlessness (Rowland 1998; Mynarska et al. 2015). This dynamic highlights the importance of the temporal dimension in this type of study and the useful distinction between temporary and permanent childlessness (Bloom and Pebley 1982).

Tanturri and Mencarini (2008) provide an interesting portrait of voluntarily childfree women in Italy. The lack of a stable partnership seems to be an important cause, but so it is voluntary childlessness among couples (about one third of couples). The latter is more common in urban environments, among women with less traditional value orientations (less religious and choosing nonmarital living arrangements) and with higher educational attainment. Nevertheless, Tanturri and Mencarini (2008) also highlight the fact that voluntarily and involuntarily childless women share a common obstacle to motherhood, namely the experience of a difficult entry into the labor market. This might be a structural constraint to early childbearing that influences the decision later in life to remain childless. An evaluation of the rationale behind voluntary childlessness in Italy goes beyond the scope of this article, but an implicit contribution of our study is that we move forward the debate on whether childlessness has structural 
socioeconomic roots beyond the cultural, physical, or circumstantial reasons to have no children. ${ }^{11}$

\section{Data and methods}

As mentioned, the present paper aims at testing the existence of a link between the recent economic dip and childlessness in Italy, investigating whether the Great Recession had a permanent effect on fertility in terms of forgone births. The latter is difficult to identify because, to investigate whether the total number of children these women had is higher or lower in comparison to women not involved in the crisis, researchers need to observe the complete fertility of women who spend part of their reproductive years during the recession.

To solve this problem, we follow, as closely as possible, the approach by Comolli and Bernardi (2015) who apply the method of difference-in-difference (DID) to pseudocohorts of American women close to the end of their reproductive lives, to test the existence of an effect of the Great Recession on the cohort's childlessness rates.

Pseudo (or synthetic) panel data is pooled cross-sectional data that is collected over time (Deaton 1985). Individuals are pooled together according to some time invariant characteristics (such as year of birth, race, or gender) and then these similar individuals are followed over time. Information is collected longitudinally, not from the same individuals, but from random samples of individuals that share those particular time-invariant characteristics. In the present case, we focus on Italian women born in particular cohorts: Because we are interested in estimating the permanent effect of the recession, we focus on childless women close to the end of their reproductive lives (around 40 years old) for whom a postponement of the first child is likely to mean forgone births.

\footnotetext{
${ }^{11}$ Likewise, it is paramount to understand that the decision to have children or not (the 'extensive' margin of fertility) is radically different from the decision of parents to have or not have another child (the 'intensive' margin of fertility). This is especially important in Italy, a context where the consensus in the literature is that almost all women want to have at least one child (Goldstein et al. 2013; Castiglioni and Dalla-Zuanna 2009). The Eurobarometer 2011 data (Testa 2014) reveal that in Italy, for $23 \%$ of women aged 25 to 39 , the ideal family size is one child only. (In Europe, the proportion is larger in only Germany and Austria.) Moreover, the average personal ideal of family size has significantly declined over time, especially for women over 40 (those who have already experienced all the difficulties related to becoming mothers). In 2001, the ideal was higher than 2.2, but it is lower than 2 in 2011. Another crucial issue is that the cross-country correlation between the percentage of childless individuals and the proportion of men and women who have fewer children than they want is positive. In countries like Italy, where most parents are unsatisfied with the number of children they have, the childlessness rate is also higher that the European average. Thus, even if the ideal family size in Italy is declining over time and childlessness rates are growing, most Italian women still end up having at least one child (Caltabiano, Castiglioni, and Rosina 2009).
} 
The analyses are based on the 2004-2013 Italian Labor Force Survey (LFS) by Istat. ${ }^{12}$ The number of biological resident children is retrievable from the indication of the type of relationship with the reference person of the survey. In more detail, based on the parental relations within the family, we identified those women who are mothers and those who are not. ${ }^{13}$ Our dependent variable is binary: being childless or not.

The LFS is useful because, first, it has the necessary large sample size needed for a pseudo-cohort study of childless women where we select only a restricted group of them (175,000 individuals and 70,000 households are interviewed each quarter of the year). Second, the LFS covers many years up to the very recent; and, third, the LFS reports detailed demographic information that could be useful to refine the analysis and investigate whether there are heterogeneous effects of the recession on childlessness. Given the illustrated geographical variation in the Italian context and the educational differentials in fertility trends, and using a sample size that allows us to do so, we complement our investigation of the effect of the recession on cohorts' childlessness by analyzing the differential impact across geographical divisions and women's educational groups.

First, based on the recession periods and the trend in the TFR in Italy, we chose the recession and nonrecession years. The financial crisis started in the summer of 2007 in the United States, but the first quarter of negative growth in Italy was registered one year later, in the summer of 2008, and the negative GDP growth persisted until mid2009 (see Figure 1) ${ }^{14}$ As mentioned, after a period of illusory positive growth in 2010, Italy entered a new recession period in 2011 that lasted until mid-2013. We argue that these two dips are part of the same crisis that was never really interrupted, and thus we consider the entire period 2009-2013 as a recession period. Moreover, in the period 2008-2010, the crisis in Italy had not yet produced significant effects on the labor market, and it had not yet revealed its persistence over time. Given the lag between macroeconomic phenomena, fertility planning, and fertility realizations, we selected 2010 as the last year of nonrecession births. We also selected 2010 because it was the last year of the peak of the TFR (see Figure 1). The babies born in 2010, we argue, are the last that were planned in 2008 and conceived in 2009, at the onset of the Great Recession.

\footnotetext{
${ }^{12}$ See Istat (2006) for a detailed description of the survey methodology. The data has been accessed and the analyses have been carried out by the authors at the Istat's Laboratorio per l'Analisi dei Dati ELEmentari (ADELE) in Florence.

${ }^{13} \mathrm{We}$ acknowledge that the way the childlessness variable is constructed is less that optimal, women not being directly asked about the number of children they ever had. As shown elsewhere (Comolli and Bernardi 2015), however, the measurement error in the dependent variable should not affect our estimate of the effect of the crisis on childlessness. Measurement error in the dependent variable affects only standard errors.

${ }^{14}$ The quarterly GDP variation peaked in mid-2009 at $-5.5 \%$ compared to the $-3 \%$ of the United States (OECD 2017).
} 
A final crucial reason to select 2009 as the last nonrecession year (and 2010 as last year of nonrecession births) is technical: We can only use the data starting from $2004 .^{15}$ Since we need to group women in birth cohorts of at least three years (to have a large enough sample size but small enough to include in each pseudo-cohort only the very similar women) and we include three groups (treatment, control, and placebo), we could not select any year earlier than 2010 as the last year of nonrecession births to be able to include all the three groups. ${ }^{16}$

Figure 1: The pseudo-panel selection

\begin{tabular}{|c|c|c|c|c|c|c|c|c|c|c|}
\hline & 2004 & 2005 & 2006 & 2007 & 2008 & 2009 & 2010 & 2011 & 2012 & 2013 \\
\hline & | II III & | || ||| & I I II III IV & I II III IV & I II I & 1111 & $1 \mathrm{I} \mathrm{II} \mathrm{IIII} \mathrm{IV}$ & I || ||| || & I II III IV & I I II III IV \\
\hline \multicolumn{11}{|l|}{ TFR trend } \\
\hline \multicolumn{11}{|c|}{ Recession } \\
\hline $\begin{array}{l}\text { T (1974- } \\
1976)\end{array}$ & & & & & & & $34-36$ & & & $37-39$ \\
\hline $\begin{array}{l}C(1971- \\
1973)\end{array}$ & & & & $34-36$ & & & $37-39$ & & & \\
\hline $\begin{array}{l}P(1968- \\
1970)\end{array}$ & $34-36$ & & & $37-39$ & & & & & & \\
\hline
\end{tabular}

Source: Elaboration of the authors.

We select the groups (the pseudo-panels) of women as shown in Figure 1. As the treatment group, we select childless women who turned 34-36 years old exactly in 2010 (thus being 37-39 years old in 2013). These childless women born in 1974-1976 spent the last years of their reproductive lives (late thirties) during the Great Recession, and they had to decide whether to have their first child or not during these years. We compare this treatment group to another pseudo-cohort of women (control group) who were born three years before (1971-1973) and turned the same age (34-36 in 2007 and 37-39 in 2010), just before the onset of the crisis. We argue that the only difference between these two random groups of women is that women in the first group, the treatment group, spend their last years of reproductive life (37-39) during the economic turmoil (2010-2013), while the control group spends that time in a noncrisis period (2007-2010).

\footnotetext{
${ }^{15}$ We could not use the data before 2004 because the collection and the sampling method of the Italian Labor Force Survey are not comparable.

${ }^{16}$ However, as a robustness check, we replicated the analyses using 2009 and 2011 as the last nonrecession birth years and restricted the birth cohorts to two years. We did not find any significant difference in the results.
} 
We initially select the maximum age at which we measure permanent childlessness at 39 years old because, in the data, we do not have information about how many children each woman has; we know only about the presence of any resident children in the household. This means that we might be underestimating the number of children each woman has, given that some of the children might have left the parental household. Restricting the age at which we measure completed fertility allows us to limit the impact of this measurement error in our dependent variable. ${ }^{17}$

However, even if the probability of conceiving is greatly reduced after the age of 39 , it is still possible that women have children after that age. Also, completed fertility is usually measured in the literature as not earlier than 44 years old. Therefore, to ensure the robustness of our estimates, we replicate the analysis, changing the age at which we measure permanent childlessness. Beyond looking at women 37-39, we also investigate the probability of remaining childless for women who, at the end of the analyzed period, are 38-40 and 42-44. Finally, we also pick a placebo group of women who - like the control group - did not leave their last years of reproductive life during the recession (34-39 years old in the period 2004-2007).

When we try to estimate the impact of the crisis on childlessness, the identification is complicated by the presence of two different effects in the variation of childlessness rates over time: the period and the cohort effects. If we only look at the difference between the proportion of childless women at 44 years old in 2013 and the same proportion of childless women at the age of 44 in 2010, we cannot differentiate the period from the cohort effect (Eq. 1).

$$
\Delta=\left(\mathrm{Y}_{\mathrm{T}, 1 \mid \mathrm{T}=1}-\mathrm{Y}_{\mathrm{C}, 1 \mid \mathrm{T}=1}\right)
$$

However, we can use the trend over time in childlessness in the control group to de-trend the period changes in childlessness in the treatment group, thus obtaining (at least in close approximation) the period effect of the crisis on cohort childlessness (Eq. 2).

$$
\Delta \Delta=\left(\mathrm{Y}_{\mathrm{T}, 1 \mid \mathrm{T}=1}-\mathrm{Y}_{\mathrm{T}, 0 \mid \mathrm{T}=0}\right)-\left(\mathrm{Y}_{\mathrm{C}, 1 \mid \mathrm{T}=1}-\mathrm{Y}_{\mathrm{C}, 0 \mid \mathrm{T}=0}\right)
$$

Equation 3 illustrates the regression model that we use in the multivariate analyses. Woman $i$ 's individual-level probability of remaining childless depends on her age (the variable 'Post,' which is equal to 1 for women in the age interval that we considered for complete fertility, e.g., 37-39 in Figure 1) and her birth cohort (the variable 'Treat,' which is equal to 1 if she is born in the treatment birth cohort, e.g., 1974-1976 in

\footnotetext{
${ }^{17}$ We can easily suppose that in Italy, given the late age at leaving the parental home (Eurostat 2017), only a very small number of children have already left when mothers are aged 39.
} 
Figure 1), which jointly determine whether this woman spends the last years of her reproductive life during the Great Recession. This joint probability is captured by the coefficient $\beta_{3}$ of the interaction term in Eq. 3 (DID=Post*Treat), namely the differencein-difference estimate of the period effect of the crisis on the treatment group with respect to the control group. The analysis is replicated comparing the control and the placebo groups of childless women and different age groups at which we measure complete fertility (namely at 37-39, 38-40, and 42-44).

$$
\operatorname{Prob}(\text { Childless })_{\mathrm{i}}=\alpha+\beta_{1} * \text { Post }_{\mathrm{i}}+\beta_{2}{ }^{*} \text { Treat }_{\mathrm{i}}+\beta_{3}{ }^{*} \text { DID }_{\mathrm{i}}+\varepsilon_{\mathrm{i}}
$$

As suggested by the description of the Italian context in Section 3, neither the intensity of the crisis nor the fertility behavior is homogenous within the country. The analysis is thus further replicated, adding the differentiation by geographical division of residence (northeast, northwest, center, south, and islands) ${ }^{18}$ and women's educational level (primary, lower secondary, higher secondary, university diploma, and university degree). ${ }^{19}$

We ran separate regression for each group for the ease of interpretation of the estimates and because, conceptually, it is as if we were comparing different pseudopanels of women. We consider these two variables as being time-invariant characteristics (which might be a reasonable assumption by the age of 30 or more, given the characteristics of the Italian population) and we assume that women residing in the north are more similar to each other compared to women living in the center or in the south (and the same applies to primary-educated women compared to universityeducated women). The latter assumptions of time-invariance of the region of residence and the educational level on which we base the pseudo-cohort selection, however, should be taken a bit more cautiously compared to the same assumption about gender and year of birth. In fact, while the latter are clearly time-invariant characteristics, women could move from one region to another to rejoin their partner or for personal working reasons. Also, both unobservable variables could be affected by the crisis, and certainly could affect women's likelihood of becoming mothers. Furthermore, even though it is not very common in Italy, adult education exists, and we cannot rule out the possibility that women increase their educational level between the ages of 30 and 40 .

\footnotetext{
${ }^{18}$ Northeast: Friuli Venezia-Giulia, Veneto, Trentino Alto-Adige, Emilia Romagna. Northwest: Piemonte, Lombardia, Liguria. Center: Toscana, Umbria, Marche, Lazio. South: Abruzzo, Molise, Campania, Calabria, Basilicata, Puglia. Islands: Sicilia, Sardegna.

${ }^{19}$ Primary: No education or primary school. Lower secondary: middle school or some high school. Upper secondary: completed high school. University diploma: diploma from cultural institutions or Laurea Breve (not followed by a master). University degree: bachelor degree or higher.
} 
However, on average we judge that these two variables are sufficiently stable in the period considered and substantially time-invariant. ${ }^{20}$

\section{Results}

In this section, we present the descriptive findings on the trends in childlessness among Italian women during the years of crisis and then the results of the difference-indifference regressions.

\subsection{Descriptive results}

Figure 2 shows the proportion of childless women in the different cohorts we selected. The dark blue lines show the decline in childlessness between the ages of 34-36 and 37-39 in the three different cohorts: the treatment cohort of women born in 1974-1976 (the thick dark blue line on the right side), the control cohort born in 1971-1973 (the thin dark blue line in the middle), and the placebo cohort of women born in 1968-1970 (the dotted dark blue line on the left side). To test the robustness of our results, we add estimates for women in different age groups (lighter blue lines): between 35-37 and 38-40 (for the cohorts: 1973-1975 [T]; 1970-1972 [C]; 1967-1969 [P]) and between 39-41 and 42-44 (for the cohorts: 1969-1971 [T]; 1966-1968 [C]; 1963-1965 [P]).

First, Figure 2 shows that younger cohorts display a higher proportion of women remaining without children in all age groups. The increase seems more pronounced between the cohort of women born in the late sixties (the placebo groups indicated by the dotted lines) and the cohorts born in the early seventies who completed their fertility before the onset of the crisis (almost a $+5 \%$ increase in childlessness both by the late thirties and the early forties).

According to our estimates, in the youngest birth cohort included in the analysis for whom we could observe complete fertility until the age of 44 in 2013 (women born in 1969-1971), the proportion of permanent childlessness is about $24 \%$. In the same cohort of women, at the age of 40 , about $26 \%$ were childless. In the birth cohort of the mid-1970s (those born five years later), at the latest age at which we can observe complete fertility (namely at 40 years old), the proportion of women without children is at $28-30 \%$.

\footnotetext{
${ }^{20}$ For instance, we checked the robustness of our assumption by controlling in our models for whether women migrated to another region (in the last year), and results were not affected (detailed estimates available upon request).
} 


\section{Figure 2: Childlessness proportion in selected age groups and years}

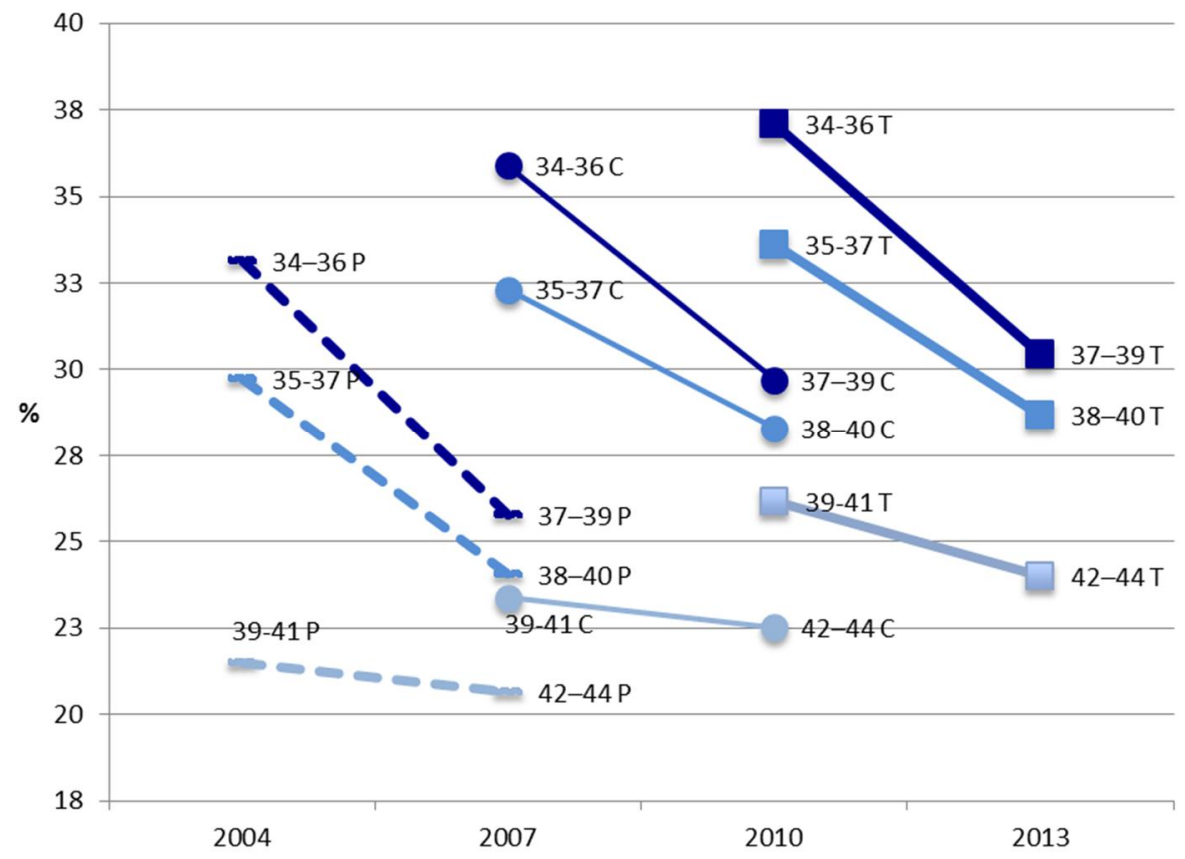

Source: Elaboration of the authors based on the Italian Labor Force Survey (LFS) data 2004-2013 accessed through the Laboratorio per l'Analisi dei Dati ELEmentari (ADELE) of Istat in Florence.

This is result diverges from the evidence reported in the United States (Comolli and Bernardi 2015), where the incidence of childlessness was declining in younger cohorts. In fact, even if the proportion of permanently childless women in the two countries is now rather similar (about $23-25 \%$ at completed fertility), in Italy, contrary to what happened in the United States, this proportion has steadily increased since the birth cohorts of the mid 1950s (Tanturri and Mencarini 2008). Even during the first years of the 2000 s, when fertility rates were increasing and childlessness was declining in the United States and in other European countries, in Italy (despite the recuperation of births and the rising TFR) childlessness kept increasing.

It is useful, for the interpretation of the results in the next section, to look more closely to these divergent long-term trends. Figure 3 compares rates of childlessness in Italy and the United States at the age of 40-44 across cohorts of women born between 1900 and 1975. The picture clearly shows that while in the United States the increase in childlessness had already started in the birth cohorts of the early forties, the rise in Italy 
started in much younger cohorts, born 15 to 20 years later. Furthermore, the increase in childlessness in the United States has been quite gradual between women born in the 1940s and in the mid-1960s, and it has stabilized in the following cohorts below $20 \%$. In contrast, in Italy, the share of childless women has steeply increased from $10 \%$ among women born in the late 1950 s to $20 \%$ among women born a decade later. The rate of childlessness in Italy has surpassed that of the United States among women born in the 1970s (the last for whom we can observe complete fertility), getting close to $25 \%$.

Figure 3: Cohort childlessness in Italy and the United States (1900-1975) at age 40-44 (percentage of childless women)

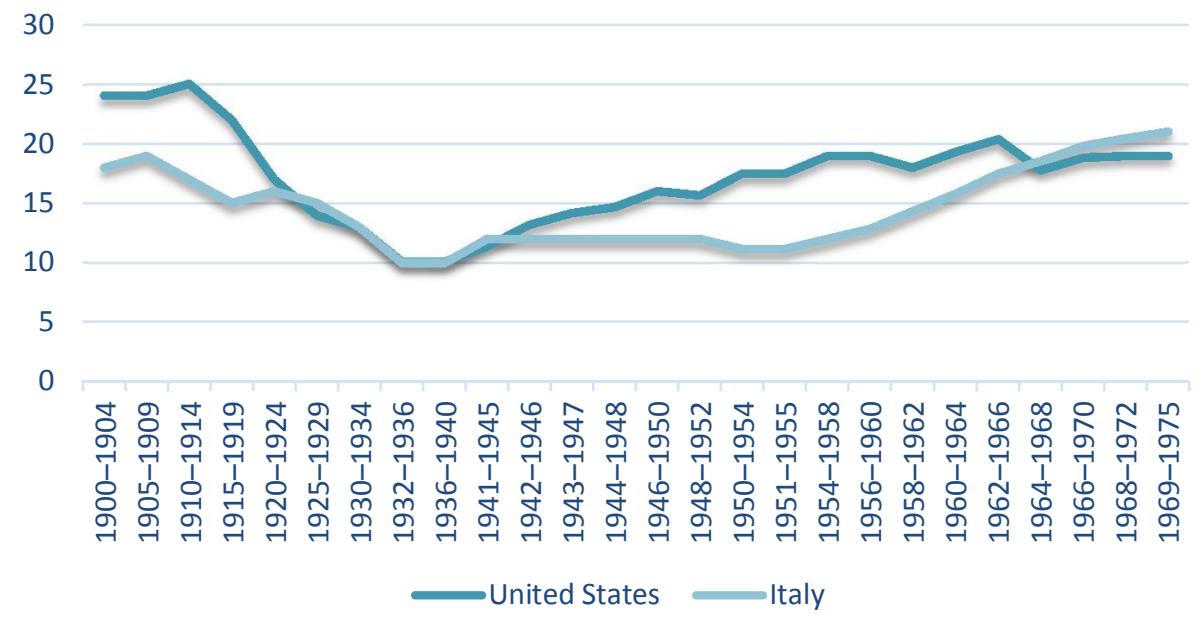

Source: Elaboration of the authors based on Dykstra (2009) and Rowland (2007) for birth cohort until the mid-1930s for the United States and the mid-1950s for Italy. Authors' estimates on Istat, Eurostat, and Human Fertility Database data from the 1955 cohort for Italy. United States Census Bureau National Vital Statistics data from the 1935 cohort for the United States.

The second interesting fact illustrated in Figure 2 is that the decline in childlessness is steeper in the late thirties compared with the early forties, where the biological limits of fecundity reduce the probability that women conceive and the likelihood of remaining permanently childless is higher (McDonald et al. 2011).

Finally, in terms of the effect of the Great Recession for childlessness between 2010 and 2013, although we cannot come to definite conclusions just from this graphical descriptive representation, there seems to be a steeper decline in the proportion of women without children between 2010 and 2013 compared to the decline 
between 2007 and 2010 (and 2004 and 2007), and this seems to be especially evident at older ages, namely for permanent childlessness measured at 42-44 years old (Figure 2).

These descriptive results seem to indicate that Italian women, who happened to be childless in their late thirties during the crisis, accelerated their first birth compared to women of the same age just before the recession. The problem with these descriptive speculations is that we cannot differentiate between the cohort and period effect in childlessness. To identify that, we turn to the results of the difference-in-difference regression in next paragraph.

\subsection{Difference-in-difference regression results}

The results presented here use figures that report the coefficients of multivariate regression. Complete tables are reported in the Appendix.

Figure 4 shows the difference-in-difference estimates of a linear probability model of the total period effect of the Great Recession, net of cohort effects, on the probability that women in the Italian sample remain childless. ${ }^{21}$ The figure presents the results in different age groups and reports the placebo difference-in-difference estimates of the difference in childlessness between cohorts who did not go through the crisis.

The results of the multivariate regression are in line with the descriptive results illustrated above. They show that, in all age groups considered, there was an increase in childlessness, net of cohort effects, in the years before the crisis. However, after 2010, the proportion of Italian women remaining without children until their late thirties and early forties declined. Both this decline and the previous increase are quite small, reaching just a $+2 \%$ in the placebo group of women 37-39 in 2010 versus women of the same age in 2007, and a $-1 \%$ for women in the early 40s in 2013 versus women of the same age in $2010 .^{22}$ In magnitude, these estimates are close to those obtained for the United States (Comolli and Bernardi 2015). The 2\% increase in childlessness between 2007 and 2010 (1\% decline between 2010 and 2013) among women age 37-39 represents the fluctuation in childlessness due to period effect only, isolated from the cohort trends. In other words, net of the long-term increasing trend in cohort childlessness, we identified a feeble acceleration of this trend due to period conditions

\footnotetext{
${ }^{21}$ See Table A-1 in Appendix.

${ }^{22}$ Notice, however, that these estimates cannot be considered as pure causal estimates of the effect of the recession on childlessness between the control group and the treatment group because we did not find a zero placebo effect. For the causal effect to be correctly identified, there should be no effect of the treatment in absence of the treatment, namely no period effect beyond the cohort effect between the control and the placebo group. We attribute these findings to the very strong and persistent cohort trend of increasing childlessness illustrated in Figure 3 that overcomes any period fluctuations, even those due to the Great Recession.
} 
that favored childlessness in 2007-2010 and a weak slowdown in the trend due to period conditions buffering childlessness in 2010-2013.

Our interpretation of this result is that, in light of the continuous and steep increase in cohort childlessness rates in Italy among women around and over 40 years old (Figure 3), any period effect represents only a short-term fluctuation, limited in intensity, within a context of a long-term strong rise in childlessness, the Great Recession being no exception.

\section{Figure 4: Difference-in-difference estimates of the effect of the crisis on} childlessness (versus placebo estimates)

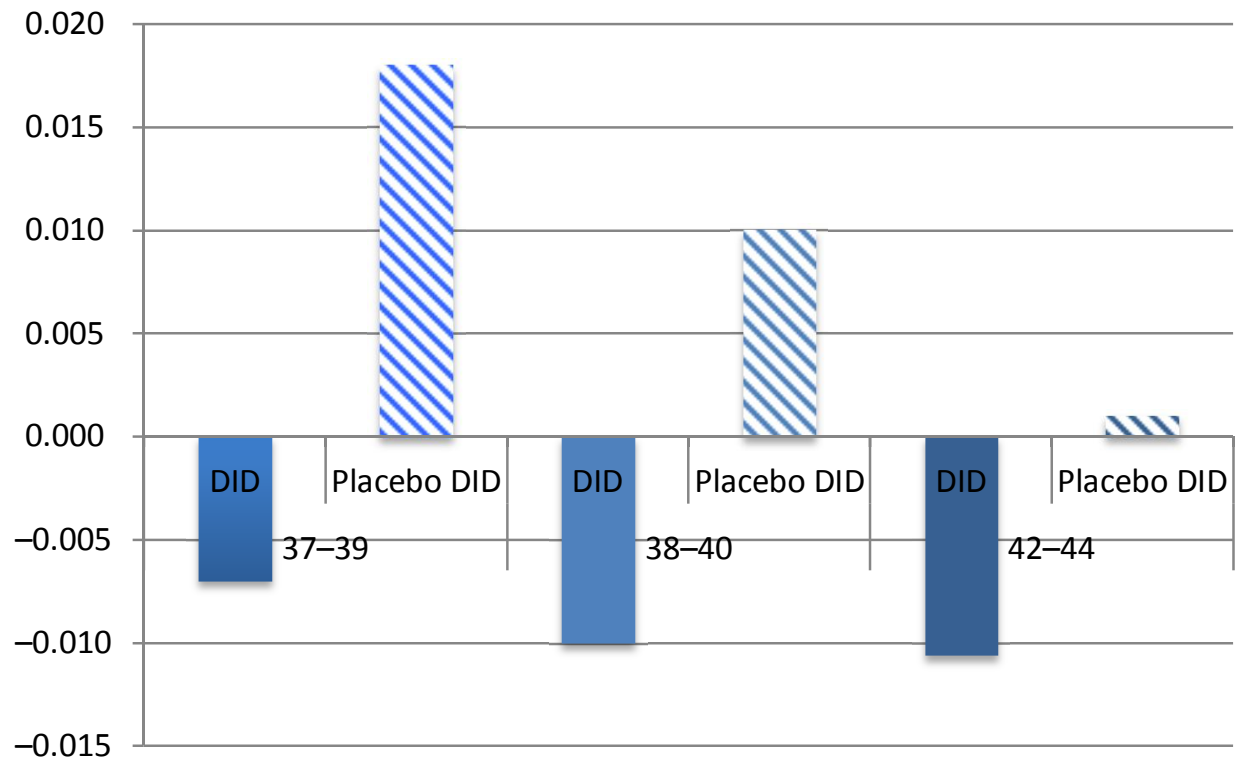

Source: Data of Table A-1 in Appendix. Elaboration of the authors based on the Italian Labor Force Survey (LFS) data 2004-2013 accessed through the Laboratorio per l'Analisi dei Dati ELEmentari (ADELE) of Istat in Florence.

However, these general results might be averaging out any heterogeneous effect of the crisis on childlessness on specific groups of Italian women. To investigate this, Figure 5 reports the estimates of the period effect of the crisis on childlessness by geographic division (northwest, northeast, center, south, islands). ${ }^{23}$ Here, the only increase in the probability of women being childless is registered in two regions: the

${ }^{23}$ For simplicity, the placebo difference-in-difference estimates are not reported. See Table A-2 in the Appendix for complete regression coefficients. 
center region for women around 40 ( $+6 \%$ among women $38-40$ years old and $+2 \%$ among women $42-44$ years old), and in the islands (Sicily and Sardinia) for women 42 44 years old $(+2 \%)$. We also register an increase in the probability of childlessness among women in the age range 37-39 living in the northwest of Italy. As before, we can interpret this as a slightly larger tendency among women around and over 40 to postpone first births during the crisis (2010-2013) in the center and in Sicily and Sardinia (acceleration in the increasing trend in childlessness), compared to the northern regions, however, no clear pattern emerges from the geographical divisions.

\section{Figure 5: Difference-in-difference estimates of the effect of the crisis on} childlessness by Italian geographic divisions

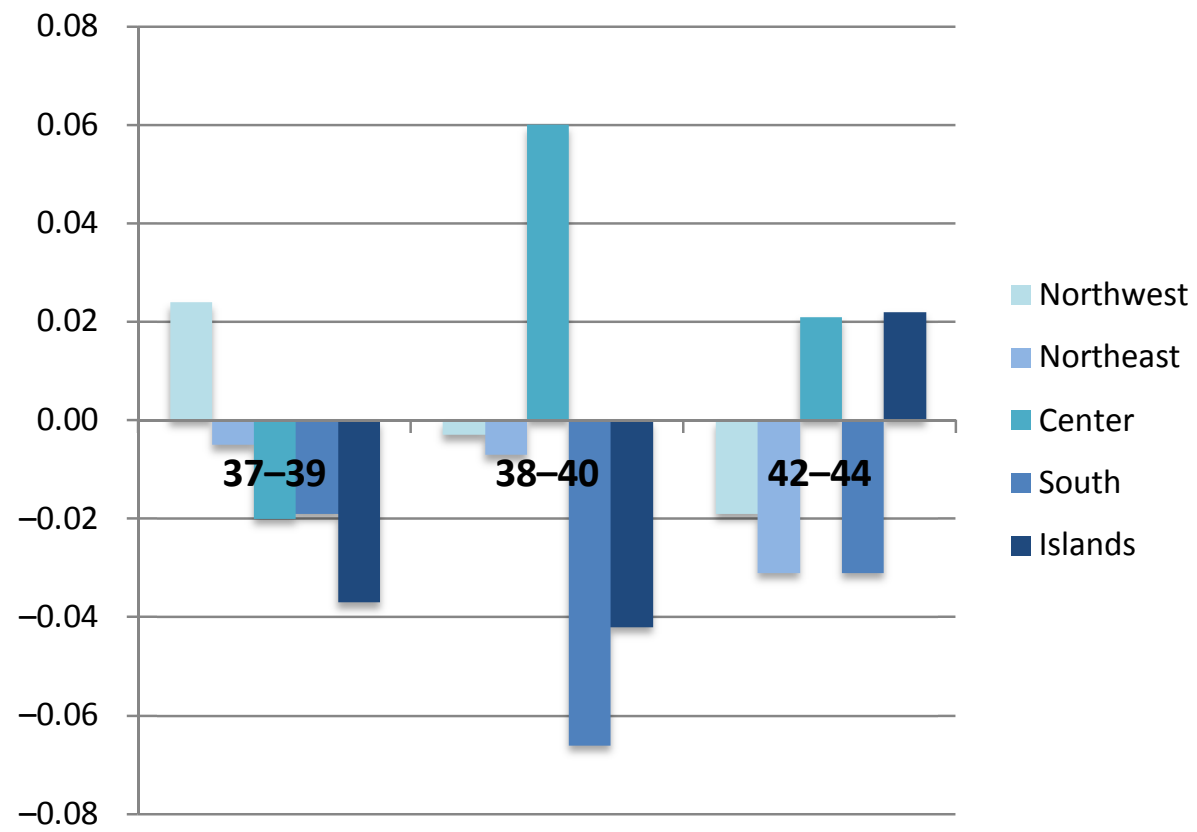

Source: Data of Table A-2 in Appendix. Elaboration of the authors based on the Italian Labor Force Survey (LFS) data 2004-2013 accessed through the Laboratorio per l'Analisi dei Dati ELEmentari (ADELE) of Istat in Florence.

Figure 6 instead reports the estimates across women's educational levels (primary; lower secondary; upper secondary; university diploma and university degree). ${ }^{24}$

\footnotetext{
${ }^{24}$ See Table A-3 in Appendix.
} 
Here the trend is clearer: On average, in all age groups considered, among women with either very low (primary) or very high (university degree) education, the probability of remaining childless during the years of the crisis declined in comparison to their cohort trend, while this probability increased among women with mid education. The latter increase in childlessness is at the maximum among women with a university diploma in the age range of 38-40 years old (+8\%) and $42-44$ years old (more than $+3 \%$ ). On top of the long-term increase, we register a clear acceleration in childlessness rates during the Great Recession only among mid-educated Italian women. No other educational group displays any tendency in postponing childbearing beyond the long-term cohort effect already in place before the crisis.

\section{Figure 6: Difference-in-difference estimates by women's educational level}

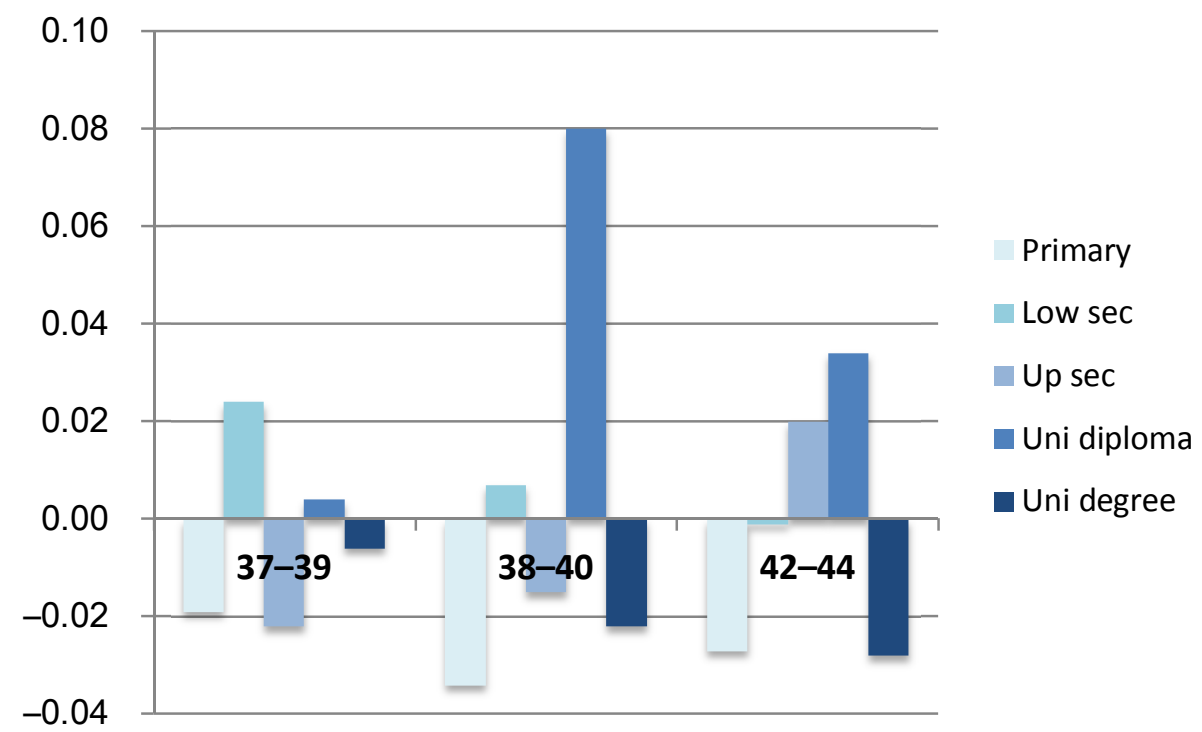

Source: Data of Table A-3 in Appendix. Elaboration of the authors based on the Italian Labor Force Survey (LFS) data 2004-2013 accessed through the Laboratorio per l'Analisi dei Dati ELEmentari (ADELE) of Istat in Florence.

\section{Discussion}

Most of the studies on how business cycles affect fertility argue that fertility responds to recessions with a temporary postponement of births, concentrated on the first child 
and among the younger strata of the population. However, a recent paper by Comolli and Bernardi (2015) finds a permanent negative effect, even if limited in magnitude, of the Great Recession in the United States on childless white women in their late thirties. In light of these results, in this paper we test whether a similar effect can be found in a very different context, i.e., Italy.

The innovation of this study is that we focus on Italy, a country where childlessness is a recent phenomenon, but also characterized by persistent low fertility, and severely hit by the economic downturn due to the 2008 crisis. In particular, we estimate whether there is an effect of the crisis on permanent childlessness. To do that, we apply a difference-in-difference method to synthetic cohorts of Italian childless women in their late thirties and early forties to assess whether the crisis had a permanent impact on childlessness rates (lost births). Presumably, in fact, these women who are close to the end of their reproductive lives will not have another chance to become mothers afterward. We use the large samples of 2004-2013 Italian Labor Force Survey (LFS) by Istat to compare cohorts' childlessness rates across phases of the Great Recession.

Another contribution of this paper is that we further disentangle the effect of the crisis on childlessness across macro-regions of residence of Italian women and across detailed educational levels. This allows us to speculate on the mechanisms that could explain our findings.

The descriptive results show a steeper decline in the proportion of women without children between 2010 and 2013 compared to the decline between 2007 and 2010 (and 2004 and 2007), and this seems to be especially evident at older ages, namely for permanent childlessness measured at 42-44 years old. This result indicates that Italian childless women, who happened to be in their late thirties during the crisis, accelerated having their first child compared to women of the same age just before the recession. This is in contrast with the results obtained regarding American women.

The results of the difference-in-difference regression are in line with the descriptive results. In all age-ranges considered, while childlessness increased in the years before the crisis, after 2010 the proportion of Italian women remaining without children until their late thirties and early forties declined. Notice that what we are measuring in this model is the eventual exceptional acceleration of childlessness among older women due to the crisis (measured as a period effect). Our findings show that the exceptional spike found in the United States (Comolli and Bernardi 2015) did not take place in Italy.

We argue that the main explanation for this divergent result lies in the different long-term trends in cohort childlessness in the two countries (illustrated in Figure 3): fairly stable in the United States, significantly increasing in Italy. Our conclusion is that the strong and steep increase in cohort permanent childlessness rates among Italian 
women in the last decade absorbs any period effect, including the consequences of the Great Recession. ${ }^{25}$

If we look at the heterogeneous effect of the crisis on childlessness across separate groups of Italian women, we find no clear geographical pattern in childlessness during the crisis. Except for the center and the islands (Sicily and Sardinia), in most of the regions considered, during the crisis we find a decline in childlessness. As mentioned in Section 3, childlessness has traditionally been higher in the south compared to the center and the north of Italy, but in the latter regions it has recently started to increase (Tanturri and Mencarini 2008). Previous empirical evidence also shows that the largest decline in first births has been registered in the northern Italian regions. Our results tend to indicate that, due to the crisis, permanent childlessness (among women over 40 years old) might rise in the center and the islands, ${ }^{26}$ while in the north the postponement of first births might still be recuperated after the crisis (where a slight increase in childlessness is registered among only women aged 37-39 - women who potentially could, even if not easily, recover their first birth).

We also estimate the effect of the crisis on childlessness across detailed educational levels, showing that women with either very low (primary) or very high (university degree) education tend to accelerate their entrance into motherhood, notwithstanding the crisis. The uncertainty generated by the Great Recession in Italy increased childlessness rates only among older women with average education (upper secondary and university diploma).

Both the very low and very highly educated childless women are strongly selected groups. The latter are women who postpone childbearing as long as they can attend tertiary education and pursue a rewarding career in the labor market. Highly educated women who have children in their late thirties to early forties during the crisis might represent women who intended to have children but postponed it as long as possible. The latter have been touched less by the economic insecurity generated by the recession ${ }^{27}$ and they might also be more capable of anticipating their declining probability of conceiving at older ages, therefore they have both the financial and social capital resources to avoid modifying their reproductive intentions, having their first child even during the crisis, if they want.

This argument also explains why the only increasing effect of the crisis on childlessness is found among women with middle education. These women are the ones who, in the middle of the education and income distribution, are more likely to be influenced in their family-formation and childbearing decisions by the financial

\footnotetext{
${ }^{25}$ This is also the reason why we do not find a zero placebo effect.

${ }^{26}$ This result is consistent with what has been hypothesized among the consequences of the economic crisis for southern Italy (Svimez 2015).

${ }^{27}$ The results of a recent Istat survey show that men and women who hold a degree were less involved in the unemployment spike consequent to the economic crisis (De Rose and Strozza 2015).
} 
constraints generated by the crisis, such as an unemployed partner, an underqualified employment, or an involuntary part-time job.

Primary educated women, instead, have no education at all or with primary school only, which means that they are likely to be very disadvantaged. ${ }^{28}$ These women arrive childless at the age of 35 , notwithstanding their larger probability of adhering to the social norm of motherhood.

Answering the question of why these women suddenly have their first child during the crisis would require another study. However, if we want to speculate on what could lead to this surge of births among disadvantaged women during exceptionally uncertain conditions, we might point to a strategy to reduce uncertainty (Friedman, Hechter, and Kanazawa 1994). Given that their personal, financial, and employment conditions are already very arduous, these women might react to the even greater insecure situation by reverting to their role of housekeepers and mothers. Edin and Kefalas (2011), in their study of the childbearing behavior of very disadvantaged women in the United States, describe a similar behavior. Since they realize that the end of their reproductive life is approaching and that they will never find fulfillment in the labor market, they might be willing to accept a relatively unsatisfying partner, only to form a family and become mothers, and thus realize themselves.

\section{Acknowledgements}

The research leading to these results has received funding from the Strategic Research Council of the Academy of Finland (Decision Number: 293103) for the research consortium Tackling Inequality in Time of Austerity (TITA) and financial support from the Swedish Research Council (Vetenskapsrådet) via the Linnaeus Center for Social Policy and Family Dynamics in Europe (SPaDE), grant registration number 349-20078701.

We would like to thank the Popdays 2017 and SUDA Colloquium participants for valuable comments and two anonymous referees for their very useful feedback.

Finally, we acknowledge that the microdata of the present study comes from the Istat survey "Rilevazione sulle forze di lavoro 2004-2013." Elaborations by the authors have been conducted at the Istat ADELE (Laboratorio per l'Analisi dei Dati ELEmentari) laboratory in Florence in compliance with the norms on statistical confidentiality and personal data protection. Results and opinions are the exclusive responsibility of the authors and do not constitute official statistics.

\footnotetext{
${ }^{28}$ A similar group of childless women was identified by Mynarska and colleagues (2015) to comprise one fifth of childless Italian women.
} 


\section{References}

Adserà, A. (2004). Changing fertility rates in developed countries. The impact of labor market institutions. Journal of Population Economics 17(1): 17-43. doi:10.1007/ s00148-003-0166-x.

Adserà, A. (2011). The interplay of employment uncertainty and education in explaining second births in Europe. Demographic Research 25(16): 513-544. doi:10.4054/DemRes.2011.25.16.

Baizán, P. (2005). The impact of labour market status and second and higher order births: A comparative study of Denmark, Italy, Spain and United Kingdom. Barcelona: Università Pompeu Fabra (DemoSoc working paper 2005-11).

Balbo, N., Billari, F.C., and Mills, M. (2013). Fertility in advanced societies: A review of research. European Journal of Population 29(1): 1-38. doi:10.1007/s10680012-9277-y.

Billari, F.C. and Kohler, H.P. (2004). Patterns of low and lowest-low fertility in Europe. Population Studies 58(2): 161-176. doi:10.1080/0032472042000213695.

Bloom, D.E. and Pebley, A.R. (1982). Voluntary childlessness: A review of the evidence and implications. Population Research and Policy Review 1(3): 203224. doi:10.1007/BF00140093.

Caltabiano, M. (2008). Has the fertility decline come to an end in the different regions of Italy? New insights from a cohort approach. Population 63: 157-172. doi:10.3917/pope.801.0157.

Caltabiano, M. (2016). A turning point in Italian fertility. Journal of Population Research 33(4): 379-397. doi:10.1007/s12546-016-9169-9.

Caltabiano, M., Castiglioni, M., and Rosina, A. (2009). Lowest-low fertility: Signs of a recovery in Italy? Demographic Research 21(23): 681-718. doi:10.4054/ DemRes.2009.21.23.

Castiglioni, M. and Dalla-Zuanna, G. (2009). Marital and reproductive behavior in Italy after 1995: Bridging the gap with Western Europe? European Journal of Population 25: 1-26. doi:10.1007/s10680-008-9155-9.

Cazzola, A., Pasquini, L., and Angeli, A. (2016). The relationship between unemployment and fertility in Italy: A time-series analysis. Demographic Research 34(1): 1-38. doi:10.4054/DemRes.2016.34.1. 
Comolli, C.L. (2017). The fertility response to the Great Recession in Europe and the United States: Structural economic conditions and perceived economic uncertainty. Demographic Research 36(51): 1549-1600. doi:10.4054/DemRes. 2017.36.51.

Comolli, C.L. and Bernardi, F. (2015). The causal effect of the great recession on childlessness of white American women. IZA Journal of Labor Economics 4(21): 1-24. doi:10.1186/s40172-015-0037-1.

Currie, J. and Schwandt, H. (2014). Short- and long-term effects of unemployment on fertility. Proceedings of the National Academy of Sciences 111(41): 1473414739. doi:10.1073/pnas.1408975111.

De Rose, A. and Strozza, S. (2015). Rapporto sulla popolazione: L'Italia nella crisi economica [Population Report: Italy in the economic crisis]. Bologna: Il Mulino.

Deaton, A. (1985). Panel data from time series of cross-sections. Journal of Econometrics 30(1-2): 109-126. doi:10.1016/0304-4076(85)90134-4.

Del Boca, D. (2002). The effect of child care and part time opportunities on participation and fertility decisions in Italy. Journal of Population Economics 15(3): 549-573. doi:10.1007/s001480100089.

Del Bono, E., Weber, A., and Winter-Ebmer, R. (2015) Fertility and economic instability: The role of unemployment and job displacement. Journal of Population Economics 28(2): 463-478. doi:10.1007/s00148-014-0531-y.

Dykstra, P.A. (2009). Childless old age. In: Uhlenberg, P. (ed.). Handbook of the demography of population aging. Dordrecht: Springer: 671-690. doi:10.1007/ 978-1-4020-8356-3 30.

Edin, K. and Kefalas, M. (2011). Promises I can keep: Why poor women put motherhood before marriage. Berkeley: University of California Press.

European Commission (2014). Joint employment report from the Commission and the Council accompanying the communication from the Commission on the annual growth survey 2015 [electronic resource]. Brussels: European Commission. http://ec.europa.eu/europe2020/pdf/2015/jer2015_en.pdf

Eurostat (2017). Population and social conditions database [electronic resource]. Luxembourg: Eurostat. http://ec.europa.eu/eurostat/data/database 
Fokkema, T., de Valk, H., de Beer, J., and van Duin, C. (2008). The Netherlands: Childbearing within the context of a 'Poldermodel' society. Demographic Research 19(21): 743-794. doi:10.4054/DemRes.2008.19.21.

Friedman, D., Hechter, M., and Kanazawa, S. (1994). A theory of the value of children. Demography 31(3): 375-401. doi:10.2307/2061749.

Human Fertility Database (2017). Italy [electronic resource]. Rostock and Vienna: Max Planck Institute for Demographic Research and Vienna Institute of Demography. http://www.humanfertility.org/cgi-bin/country.php?country=ITA

Goldstein, J.R., Kreyenfeld, M., Jasilioniene, A., and Orsal, D.K. (2013). Fertility reactions to the 'Great Recession' in Europe: Recent evidence from orderspecific data. Demographic Research 29(4): 85-104. doi:10.4054/DemRes. 2013.29.4.

González, M.J. and Jurado-Guerrero, T. (2006). Remaining childless in affluent economies: A comparison of France, West Germany, Italy and Spain, 19942001. European Journal of Population 22(4): 317-352. doi:10.1007/s10680006-9000-y.

Inanc, H. (2015). Unemployment and the timing of parenthood: Implications of partnership status and partner's employment. Demographic Research 32(7): 219-250. doi:10.4054/DemRes.2015.32.7.

Istat (2006). La rilevazione sulle forze di lavoro: Contenuti, metodologie, organizzazione [The labour force survey: Contents, methodology and organization]. Rome: Istat (Collana Metodi e Norme [Methods and Norms Special Collection] 32).

Istat (2017). I.Stat - Italian Statistics Database [electronic resource]. Rome: Istat. http://dati.istat.it/

Kreyenfeld, M., Andersson, G., and Pailhé, A. (2012). Economic uncertainty and family dynamics in Europe. Demographic Research 27(28): 835-852. doi:10.4054/ DemRes.2012.27.28.

Kreyenfeld, M. and Andersson, G. (2014). Socioeconomic differences in the unemployment and fertility nexus: Evidence from Denmark and Germany. Advances in Life Course Research 21: 59-73. doi:10.1016/j.alcr.2014.01.007.

Lesthaeghe, R., and Willems, P. (1999). Is low fertility a temporary phenomenon in the European Union? Population and Development Review 25(2): 211-228. doi:10.1111/j.1728-4457.1999.00211.x. 
McDonald, J.W., Rosina, A., Rizzi, E., and Colombo, B. (2011). Age and fertility: Can women wait until their early thirties to try for a first birth? Journal of Biosocial Science 43(6): 685-700. doi:10.1017/S002193201100040X.

Meron, M. and Widmer, I. (2002). Unemployment leads women to postpone the birth of their first child. Population 57(2): 301-330. doi:10.3917/pope.202.0301.

Micheli, G.A. (2000). Kinship, family and social network: The anthropological embedment of fertility change in Southern Europe. Demographic Research 3(13): 1-34. doi:10.4054/DemRes.2000.3.13.

Micheli, G.A. (2012). Two strong families in southern Europe? Re-examining the geography of kinship regimes stemming from the reciprocity mechanisms between generations. European Journal of Population 28(1): 17-38. doi:10.1007/s10680-011-9245-y.

Miettinen, A., Rotkirch, A., Szalma, I., Donno, A., and Tanturri, M.L. (2015). Increasing childlessness in Europe: Time trends and country differences. Stockholm: Stockholm University (Families and Societies working paper 33).

Mills, M., Rotkirch, A., Sobotka, T., Takács, J., Miettinen, A., Faludi, C., and Nasiri, D. (2015). State-of-the-art report: Childlessness in Europe. Stockholm: Stockholm University (Families and Societies working paper 32).

Morgan, S.P., Cumberworth, E., and Wimer, C. (2011). The great recession's influence on fertility, marriage, divorce and cohabitation. In: Grusky, D.B., Western, B., and Wimer, C. (eds.). The Great Recession. New York: Russell Sage Foundation: 220-245.

Mynarska, M., Matysiak, A., Rybińska, A., Tocchioni, V., and Vignoli, D. (2015). Diverse paths into childlessness over the life course. Advances in Life Course Research 25: 35-48. doi:10.1016/j.alcr.2015.05.003.

OECD iLibrary (2017). Quarterly GDP (indicator) [electronic resource]. Paris: OECD. http://www.oecd-ilibrary.org

Rowland, D.T. (1998). Consequences of childlessness in later life. Australasian Journal on Ageing 17(1): 24-28. doi:10.1111/j.1741-6612.1998.tb00220.x.

Rowland, D.T. (2007). Historical trends in childlessness. Journal of Family Issues 28(10): 1311-1337. doi:10.1177/0192513X07303823.

Santarelli, E. (2011). Economic resources and the first child in Italy: A focus on income and job stability. Demographic Research 25(9): 311-336. doi:10.4054/DemRes. 2011.25.9. 
Schneider, D. (2015). The Great Recession, fertility, and uncertainty: Evidence from the United States. Journal of Marriage and Family 77(5): 1144-1156. doi:10.1111/ jomf. 12212 .

Sobotka, T. (2004). Is lowest-low fertility in Europe explained by the postponement of childbearing? Population and Development Review 30(2): 195-220. doi:10.1111/j.1728-4457.2004.010_1.x.

Sobotka, T. (2017). Childlessness in Europe: Reconstructing long-term trends among women born in 1900-1972. In: Kreyenfeld, M. and Konietzka, D. (eds.). Childlessness in Europe: Contexts, causes, and consequences. Dordrecht: Springer: 17-56. doi:10.1007/978-3-319-44667-7_2.

Sobotka, T., Skirbekk, V., and Philipov, D. (2010). Research note: Economic recession and fertility in the developed world: A literature review. Vienna: Vienna Institute of Demography.

Sobotka, T., Skirbekk, V., and Philipov, D. (2011). Economic recession and fertility in the developed world. Population and Development Review 37(2): 267-306. doi:10.1111/j.1728-4457.2011.00411.x.

Svimez - Associazione per lo Sviluppo dell'Industria nel Mezzogiorno (2015). Rapporto 2015 sull'economia del Mezzogiorno [2015 Report of Southern Italy Economy]. Rome: Svimez.

Tanturri, M.L. and Mencarini, L. (2008). Childless or childfree? Paths to voluntary childlessness in Italy. Population Development Review 34(1): 51-77. doi:10.1111/j.1728-4457.2008.00205.x.

Testa, M.R. (2014). On the positive correlation between education and fertility intentions in Europe: Individual- and country-level evidence. Advances in Life Course Research 21: 28-42. doi:10.1016/j.alcr.2014.01.005.

Testa, M.R., Cavalli, L., and Rosina, A. (2014). The effect of couple disagreement about child-timing intentions: A parity-specific approach. Population and Development Review 40(1): 31-53. doi:10.1111/j.1728-4457.2014.00649.x.

Vignoli, D., Drefahl, S., and De Santis, G. (2012). Whose job instability affects the likelihood of becoming a parent in Italy? A tale of two partners. Demographic Research 26(2): 41-62. doi:10.4054/DemRes.2012.26.2.

Wood, J., Neels, K., and Kil, T. (2014). The educational gradient of childlessness and cohort parity progression in 14 low fertility countries. Demographic Research 31(46): 1365-1416. doi:10.4054/DemRes.2014.31.46. 


\section{Appendix}

\section{Table A-1: Weighted linear probability model of the period effect of the Great Recession on the probability of childlessness}

\begin{tabular}{|c|c|c|c|c|c|c|}
\hline & \multicolumn{2}{|l|}{$37-39$} & \multicolumn{2}{|l|}{$38-40$} & \multicolumn{2}{|l|}{$42-44$} \\
\hline & $\Delta \Delta$ & Placebo $\Delta \boldsymbol{\Delta}$ & $\Delta \boldsymbol{\Delta}$ & Placebo $\boldsymbol{\Delta} \boldsymbol{\Delta}$ & $\Delta \Delta$ & Placebo $\Delta \boldsymbol{\Delta}$ \\
\hline $\begin{array}{l}\text { Post } \\
\text { (e.g., 37-39) }\end{array}$ & $\begin{array}{l}-0.058^{\star \star *} \\
(-0.0582- \\
-0.579)\end{array}$ & $\begin{array}{l}-0.076^{* * *} \\
(-0.076- \\
-0.0761)\end{array}$ & $\begin{array}{l}-0.042^{\star \star \star} \\
(-0.0420- \\
-0.0416)\end{array}$ & $\begin{array}{l}-0.052^{* * *} \\
(-0.0522- \\
-0.0519)\end{array}$ & $\begin{array}{l}-0.011^{* \star *} \\
(-0.011- \\
-0.0108)\end{array}$ & $\begin{array}{l}-0.012^{\star \star \star} \\
(-0.0118- \\
-0.0116)\end{array}$ \\
\hline $\begin{array}{l}\text { Treat } \\
\text { (e.g., 1974- } \\
1976)\end{array}$ & $\begin{array}{c}0.013^{\star \star \star} \\
(0.0127- \\
0.0130)\end{array}$ & $\begin{array}{c}0.026^{* \star \star} \\
(0.0257- \\
0.0260)\end{array}$ & $\begin{array}{c}0.013^{\star \star *} \\
(0.0128- \\
0.013)\end{array}$ & $\begin{array}{c}0.030^{\star \star *} \\
(0.0297- \\
0.0300)\end{array}$ & $\begin{array}{c}0.026^{\star \star \star} \\
(0.0255- \\
0.0258)\end{array}$ & $\begin{array}{c}0.019^{\star \star *} \\
(0.0185- \\
0.0187)\end{array}$ \\
\hline $\begin{array}{l}\Delta \Delta \\
\text { (Post* Treat) }\end{array}$ & $\begin{array}{l}-0.007^{\star \star *} \\
(-0.0075- \\
-0.0070)\end{array}$ & $\begin{array}{l}0.018^{\star \star \star} \\
(0.0180- \\
0.0184)\end{array}$ & $\begin{array}{l}-0.010^{\star \star *} \\
(-0.010- \\
-0.0099)\end{array}$ & $\begin{array}{l}0.010^{\star \star *} \\
(0.0101- \\
0.0105)\end{array}$ & $\begin{array}{l}-0.0106^{* * *} \\
(-0.0108- \\
-0.0104)\end{array}$ & $\begin{array}{l}0.0008^{\star \star *} \\
(0.0005- \\
0.001)\end{array}$ \\
\hline Constant & $\begin{array}{l}0.353^{\star \star \star} \\
(0.352-0.353)\end{array}$ & $\begin{array}{l}0.327^{\star \star \star} \\
(0.03265- \\
0.0327)\end{array}$ & $\begin{array}{c}0.321^{\star * *} \\
(0.3203- \\
0.3206)\end{array}$ & $\begin{array}{l}0.291^{\star \star *} \\
(0.2905- \\
0.2907)\end{array}$ & $\begin{array}{c}0.234^{\star \star *} \\
(0.2341- \\
0.2343)\end{array}$ & $\begin{array}{c}0.216^{\star \star *} \\
(0.216- \\
0.0216)\end{array}$ \\
\hline $\mathrm{N}$ & 47,653 & 54,839 & 49,341 & 56,117 & 54,420 & 61,032 \\
\hline
\end{tabular}

Source: Elaboration of the authors based on the Italian Labor Force Survey (LFS) data 2004-2014 accessed through the Laboratorio per l'Analisi dei Dati ELEmentari (ADELE) of Istat in Florence.

Note: ${ }^{\star} p \leq 0.05,{ }^{\star \star} p \leq 0.01,{ }^{* \star *} p \leq 0.001$. Robust $95 \%$ confidence intervals in parentheses. 
Caltabiano, Comolli \& Rosina: The effect of the Great Recession on permanent childlessness in Italy

Table A-2: Weighted linear probability model of the period effect of the Great Recession on the probability of childlessness across Italian geographic divisions

\begin{tabular}{|c|c|c|c|c|c|c|}
\hline & \multicolumn{6}{|l|}{ Northwest } \\
\hline & \multicolumn{2}{|l|}{$37-39$} & \multicolumn{2}{|l|}{$38-40$} & \multicolumn{2}{|l|}{$42-44$} \\
\hline & $\Delta \Delta$ & Placebo $\Delta \boldsymbol{\Delta}$ & $\Delta \Delta$ & Placebo $\Delta \Delta$ & $\Delta \Delta$ & Placebo $\Delta \Delta$ \\
\hline $\begin{array}{l}\text { Post } \\
\text { (e.g., 37-39) }\end{array}$ & $\begin{array}{l}-0.076^{\star \star *} \\
(-0.0759- \\
-0.0752)\end{array}$ & $\begin{array}{l}-0.087^{\star * *} \\
(-0.0875- \\
-0.0868)\end{array}$ & $\begin{array}{l}-0.048^{\star * *} \\
(-0.0481- \\
-0.0474)\end{array}$ & $\begin{array}{l}-0.063^{* * *} \\
(-0.063- \\
-0.063)\end{array}$ & $\begin{array}{l}0.006^{\star \star \star} \\
(0.006-0.007)\end{array}$ & $\begin{array}{l}-0.025^{\star \star *} \\
(-0.025- \\
-0.0246)\end{array}$ \\
\hline $\begin{array}{l}\text { Treat } \\
\text { (e.g., 1974-1976) }\end{array}$ & $\begin{array}{l}-0.029^{\star \star \star} \\
(-0.0294- \\
-0.0288)\end{array}$ & $\begin{array}{c}0.023^{* * *} \\
(0.0231- \\
0.0237)\end{array}$ & $\begin{array}{c}0.0014^{* * *} \\
(0.0011- \\
0.0017)\end{array}$ & $\begin{array}{l}0.016^{* * *} \\
(0.015- \\
0.016)\end{array}$ & $\begin{array}{l}0.014^{* * *} \\
(0.0141- \\
0.0146)\end{array}$ & $\begin{array}{c}0.012^{\star * *} \\
(0.011- \\
0.0118)\end{array}$ \\
\hline$\Delta \Delta$ (Post ${ }^{*}$ Treat $)$ & $\begin{array}{c}0.024^{\star \star \star} \\
(0.0235- \\
0.0245)\end{array}$ & $\begin{array}{c}0.012^{\star \star \star} \\
(0.0111- \\
0.0120)\end{array}$ & $\begin{array}{l}-0.003^{\star \star *} \\
(-0.0035- \\
-0.0026)\end{array}$ & $\begin{array}{c}0.015^{\star \star \star *} \\
(0.0148- \\
0.0158)\end{array}$ & $\begin{array}{l}-0.019^{\star \star \star} \\
(-0.019- \\
-0.018)\end{array}$ & $\begin{array}{l}0.031^{\star \star *} \\
(0.0309- \\
0.0317)\end{array}$ \\
\hline Constant & $\begin{array}{l}0.40^{\star \star \star} \\
(0.4006- \\
0.0401)\end{array}$ & $\begin{array}{l}0.377^{\star \star \star} \\
(0.377- \\
-0.376)\end{array}$ & $\begin{array}{l}0.355^{\star \star \star} \\
(0.354- \\
0.355)\end{array}$ & $\begin{array}{l}0.339^{\star \star *} \\
(0.338- \\
0.339)\end{array}$ & $\begin{array}{l}0.266^{\star \star \star} \\
(0.266- \\
0.267)\end{array}$ & $\begin{array}{l}0.255^{\star \star \star} \\
(0.255- \\
0.255)\end{array}$ \\
\hline \multirow[t]{4}{*}{$\mathrm{N}$} & 12,886 & 14,899 & 13,258 & 15,182 & 14,745 & 16,518 \\
\hline & \multicolumn{6}{|l|}{ Northeast } \\
\hline & \multicolumn{2}{|l|}{$37-39$} & \multicolumn{2}{|l|}{$38-40$} & \multicolumn{2}{|l|}{$42-44$} \\
\hline & $\Delta \Delta$ & Placebo $\Delta \Delta$ & $\Delta \Delta$ & Placebo $\Delta \Delta$ & $\Delta \Delta$ & Placebo $\Delta \Delta$ \\
\hline $\begin{array}{l}\text { Post } \\
\text { (e.g., 37-39) }\end{array}$ & $\begin{array}{l}-0.063^{\star \star \star} \\
(-0.064- \\
-0.0629)\end{array}$ & $\begin{array}{l}-0.117^{\star \star *} \\
(-0.117- \\
-0.116)\end{array}$ & $\begin{array}{l}-0.039^{\star \star \star} \\
(-0.039- \\
-0.038)\end{array}$ & $\begin{array}{l}-0.076^{\star \star *} \\
(-0.077- \\
-0.076)\end{array}$ & $\begin{array}{l}-0.005^{\star \star *} \\
(-0.006- \\
-0.005)\end{array}$ & $\begin{array}{l}-0.013^{\star * *} \\
(-0.014- \\
-0.013)\end{array}$ \\
\hline $\begin{array}{l}\text { Treat } \\
\text { (e.g., 1974-1976) }\end{array}$ & $\begin{array}{c}0.027^{\star \star \star} \\
(0.0268- \\
0.0276)\end{array}$ & $\begin{array}{l}0.0031^{* * *} \\
(0.003- \\
0.004)\end{array}$ & $\begin{array}{c}0.014^{\star * *} \\
(0.0132- \\
0.0140)\end{array}$ & $\begin{array}{l}0.028^{* * *} \\
(0.027- \\
0.028)\end{array}$ & $\begin{array}{l}0.035^{\star \star *} \\
(0.035- \\
0.036)\end{array}$ & $\begin{array}{l}0.012^{* * *} \\
(0.012- \\
0.013)\end{array}$ \\
\hline$\Delta \Delta$ (Post $^{\star}$ Treat $)$ & $\begin{array}{l}-0.005^{\star \star \star} \\
(-0.005- \\
-0.004)\end{array}$ & $\begin{array}{l}0.053^{\star * \star} \\
(0.053- \\
0.054)\end{array}$ & $\begin{array}{l}-0.007^{\star \star *} \\
(-0.007- \\
-0.006)\end{array}$ & $\begin{array}{l}0.038^{* \star *} \\
(0.037- \\
0.038)\end{array}$ & $\begin{array}{l}-0.031^{\star \star *} \\
(-0.032- \\
-0.031)\end{array}$ & $\begin{array}{c}0.008^{* * *} \\
(0.008- \\
0.0085)\end{array}$ \\
\hline Constant & $\begin{array}{l}0.372^{\star \star *} \\
(0.3718- \\
0.372)\end{array}$ & $\begin{array}{c}0.370^{\star \star \star} \\
(0.369- \\
0.369)\end{array}$ & $\begin{array}{l}0.346^{\star \star \star} \\
(0.345- \\
0.346)\end{array}$ & $\begin{array}{l}0.318^{* \star \star} \\
(0.318- \\
0.318)\end{array}$ & $\begin{array}{l}0.260^{\star \star \star} \\
(0.259- \\
0.260)\end{array}$ & $\begin{array}{c}0.247^{\star \star \star} \\
(0.247- \\
0.248)\end{array}$ \\
\hline \multirow[t]{4}{*}{$\mathrm{N}$} & 9,254 & 10,507 & 9,648 & 10,880 & 10,733 & 11,891 \\
\hline & \multicolumn{6}{|l|}{ Center } \\
\hline & \multicolumn{2}{|l|}{$37-39$} & \multicolumn{2}{|l|}{$38-40$} & \multicolumn{2}{|l|}{$42-44$} \\
\hline & $\Delta \Delta$ & Placebo $\Delta \boldsymbol{\Delta}$ & $\Delta \Delta$ & Placebo $\boldsymbol{\Delta} \boldsymbol{\Delta}$ & $\Delta \Delta$ & Placebo $\Delta \Delta$ \\
\hline $\begin{array}{l}\text { Post } \\
\text { (e.g., 37-39) }\end{array}$ & $\begin{array}{l}-0.071^{\star \star \star} \\
(-0.072- \\
-0.071)\end{array}$ & $\begin{array}{c}-0.080^{* * *} \\
(-0.081- \\
0.080)\end{array}$ & $\begin{array}{l}-0.095^{\star \star \star} \\
(-0.096- \\
-0.095)\end{array}$ & $\begin{array}{l}-0.054^{* * *} \\
(-0.054- \\
-0.053)\end{array}$ & 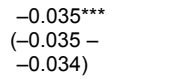 & 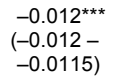 \\
\hline $\begin{array}{l}\text { Treat } \\
\text { (e.g., 1974-1976) }\end{array}$ & $\begin{array}{c}0.014^{\star \star \star} \\
(0.014- \\
0.015)\end{array}$ & $\begin{array}{l}0.047^{\star \star \star} \\
(0.046- \\
0.047)\end{array}$ & $\begin{array}{l}-0.038^{\star \star *} \\
(-0.038- \\
-0.038)\end{array}$ & $\begin{array}{c}0.072^{\star \star \star} \\
(0.0716- \\
0.0723)\end{array}$ & $\begin{array}{l}0.017^{\star \star \star} \\
(0.016- \\
0.017)\end{array}$ & $\begin{array}{c}0.029^{* * *} \\
(0.0290- \\
0.0297)\end{array}$ \\
\hline$\Delta \Delta$ (Post $^{\star}$ Treat $)$ & $\begin{array}{l}-0.019^{\star \star \star} \\
(-0.0198- \\
-0.0187)\end{array}$ & $\begin{array}{l}0.009^{\star \star *} \\
(0.008- \\
0.009)\end{array}$ & $\begin{array}{l}0.060^{\star \star *} \\
(0.060- \\
0.061)\end{array}$ & $\begin{array}{l}-0.042^{* * *} \\
(-0.042- \\
-0.041)\end{array}$ & 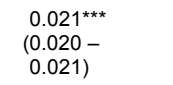 & $\begin{array}{l}-0.023^{\star * *} \\
(-0.023- \\
-0.022)\end{array}$ \\
\hline Constant & $\begin{array}{l}0.387^{\star \star \star} \\
(0.387- \\
0.388)\end{array}$ & $\begin{array}{c}0.341^{\star * \star} \\
(0.340- \\
0.341)\end{array}$ & $\begin{array}{c}0.378^{\star \star \star} \\
(0.377- \\
0.378)\end{array}$ & $\begin{array}{c}0.306^{\text {*** }} \\
(0.305- \\
0.306)\end{array}$ & $\begin{array}{l}0.257^{\star \star \star} \\
(0.257- \\
0.257)\end{array}$ & $\begin{array}{l}0.228^{\star * *} \\
(0.227- \\
0.228)\end{array}$ \\
\hline $\mathrm{N}$ & 7,598 & 8,177 & 7,788 & 8,328 & 8,494 & 9,207 \\
\hline
\end{tabular}


Table A-2: (Continued)

\begin{tabular}{|c|c|c|c|c|c|c|}
\hline & \multicolumn{6}{|l|}{ South } \\
\hline & \multicolumn{2}{|l|}{$37-39$} & \multicolumn{2}{|l|}{$38-40$} & \multicolumn{2}{|l|}{$42-44$} \\
\hline & $\Delta \Delta$ & Placebo $\Delta \boldsymbol{\Delta}$ & $\Delta \Delta$ & Placebo $\Delta \boldsymbol{\Delta}$ & $\Delta \Delta$ & Placebo $\Delta \Delta$ \\
\hline $\begin{array}{l}\text { Post } \\
\text { (e.g., 37-39) }\end{array}$ & $\begin{array}{l}-0.049^{\star * \star} \\
(-0.049- \\
-0.0485)\end{array}$ & $\begin{array}{l}-0.049^{* * *} \\
(-0.049- \\
-0.049)\end{array}$ & $\begin{array}{l}0.003^{* * *} \\
(0.003- \\
0.004)\end{array}$ & 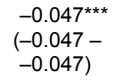 & $\begin{array}{l}-0.004^{\star \star *} \\
(-0.004- \\
-0.0036)\end{array}$ & $\begin{array}{l}0.009^{\star * *} \\
(0.008- \\
0.009)\end{array}$ \\
\hline $\begin{array}{l}\text { Treat } \\
\text { (e.g., 1974-1976) }\end{array}$ & $\begin{array}{l}0.043^{* * *} \\
(0.043- \\
0.043)\end{array}$ & $\begin{array}{l}0.0309^{* \star *} \\
(0.0306- \\
0.031)\end{array}$ & $\begin{array}{c}0.066^{\star * *} \\
(0.0658- \\
0.0665)\end{array}$ & $\begin{array}{l}0.009^{\star * *} \\
(0.009- \\
0.010)\end{array}$ & $\begin{array}{l}0.059^{\star \star *} \\
(0.0592- \\
0.060)\end{array}$ & $\begin{array}{l}0.007^{\star \star *} \\
(0.006- \\
0.007)\end{array}$ \\
\hline$\Delta \Delta$ (Post ${ }^{*}$ Treat $)$ & $\begin{array}{l}-0.019^{* * *} \\
(-0.019- \\
-0.018)\end{array}$ & $\begin{array}{c}0.0003 \\
(-0.0002- \\
0.0008)\end{array}$ & $\begin{array}{l}-0.0655^{\star \star *} \\
(-0.066- \\
-0.065)\end{array}$ & $\begin{array}{l}0.050^{* * *} \\
(0.0498- \\
0.0507)\end{array}$ & $\begin{array}{l}-0.031^{* * *} \\
(-0.0311- \\
-0.0303)\end{array}$ & $\begin{array}{l}-0.012^{\star *} \\
(-0.013- \\
-0.012)\end{array}$ \\
\hline Constant & $\begin{array}{l}0.278^{\star * *} \\
(0.277- \\
0.278)\end{array}$ & $\begin{array}{l}0.247^{\star \star *} \\
(0.246- \\
0.247)\end{array}$ & $\begin{array}{l}0.231^{* * *} \\
(0.2305- \\
0.231)\end{array}$ & $\begin{array}{l}0.221^{\star * *} \\
(0.221- \\
0.222)\end{array}$ & $\begin{array}{l}0.157^{\star * \star} \\
(0.157- \\
0.157)\end{array}$ & $\begin{array}{l}0.150^{\star * *} \\
(0.150- \\
0.151)\end{array}$ \\
\hline \multirow[t]{4}{*}{$\underline{N}$} & 10,846 & 12,620 & 11,256 & 12,929 & 12,133 & 13,879 \\
\hline & \multicolumn{6}{|l|}{ Islands } \\
\hline & \multicolumn{2}{|l|}{$37-39$} & \multicolumn{2}{|l|}{$38-40$} & \multicolumn{2}{|l|}{$42-44$} \\
\hline & $\Delta \Delta$ & Placebo $\Delta \boldsymbol{\Delta}$ & $\Delta \Delta$ & Placebo $\Delta \boldsymbol{\Delta}$ & $\Delta \Delta$ & Placebo $\Delta \Delta$ \\
\hline $\begin{array}{l}\text { Post } \\
\text { (e.g., 37-39) }\end{array}$ & $\begin{array}{c}-0.009^{* \star *} \\
(-0.009- \\
0.008)\end{array}$ & $\begin{array}{l}-0.040^{\star \star *} \\
(-0.040- \\
-0.039)\end{array}$ & $\begin{array}{l}-0.039^{\star \star \star} \\
(-0.040- \\
-0.039)\end{array}$ & $\begin{array}{l}-0.007^{\star \star *} \\
(-0.008- \\
-0.007)\end{array}$ & $\begin{array}{l}-0.028^{\star * *} \\
(-0.028- \\
-0.027)\end{array}$ & $\begin{array}{l}-0.008^{\star \star *} \\
(-0.009- \\
-0.008)\end{array}$ \\
\hline $\begin{array}{l}\text { Treat } \\
\text { (e.g., 1974-1976) }\end{array}$ & $\begin{array}{l}0.0244^{* * *} \\
(0.024- \\
0.025)\end{array}$ & $\begin{array}{l}0.010^{* * *} \\
(0.010- \\
0.011)\end{array}$ & $\begin{array}{l}0.021^{* * *} \\
(0.021- \\
0.022)\end{array}$ & $\begin{array}{l}0.023^{\star * *} \\
(0.022- \\
0.023)\end{array}$ & $\begin{array}{l}-0.016^{\star * *} \\
(-0.017- \\
-0.016)\end{array}$ & $\begin{array}{l}0.048^{\star * *} \\
(0.048- \\
0.049)\end{array}$ \\
\hline$\Delta \Delta$ (Post*Treat) & $\begin{array}{l}-0.037^{\star * *} \\
(-0.038- \\
-0.036)\end{array}$ & $\begin{array}{l}0.031^{* * *} \\
(0.030- \\
0.032)\end{array}$ & $\begin{array}{l}-0.042^{* * *} \\
(-0.043- \\
-0.042)\end{array}$ & $\begin{array}{l}-0.032^{\star * *} \\
(-0.033- \\
-0.031)\end{array}$ & $\begin{array}{l}0.022^{* * *} \\
(0.022- \\
0.023)\end{array}$ & $\begin{array}{l}-0.019^{\star \star \star} \\
(-0.020- \\
-0.019)\end{array}$ \\
\hline Constant & $\begin{array}{c}0.291^{\star \star *} \\
(0.291- \\
0.291)\end{array}$ & $\begin{array}{l}0.281^{\star \star *} \\
(0.280- \\
0.281)\end{array}$ & $\begin{array}{l}0.277^{* \star *} \\
(0.276- \\
0.277)\end{array}$ & $\begin{array}{c}0.254^{\star \star *} \\
(0.253- \\
0.254)\end{array}$ & 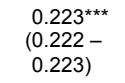 & $\begin{array}{c}0.174^{\star \star \star} \\
(0.174- \\
0.175)\end{array}$ \\
\hline $\mathrm{N}$ & 5,050 & 6,012 & 5,218 & 6,058 & 5,833 & 6,650 \\
\hline
\end{tabular}

Source: Elaboration of the authors based on the Italian Labor Force Survey (LFS) data 2004-2014 accessed through the Laboratorio per l'Analisi dei Dati ELEmentari (ADELE) of Istat in Florence.

Note: ${ }^{*} p \leq 0.05,{ }^{* *} p \leq 0.01,{ }^{* * *} p \leq 0.001$. Robust $95 \%$ confidence intervals in parentheses. 
Caltabiano, Comolli \& Rosina: The effect of the Great Recession on permanent childlessness in Italy

Table A-3: Weighted linear probability model of the period effect of the Great Recession on the probability of childlessness across women's educational level

\begin{tabular}{|c|c|c|c|c|c|c|}
\hline & \multicolumn{6}{|l|}{ Primary } \\
\hline & \multicolumn{2}{|l|}{$37-39$} & \multicolumn{2}{|l|}{$38-40$} & \multicolumn{2}{|l|}{$42-44$} \\
\hline & $\Delta \Delta$ & Placebo $\Delta \boldsymbol{\Delta}$ & $\Delta \Delta$ & Placebo $\Delta \Delta$ & $\Delta \Delta$ & Placebo $\Delta \Delta$ \\
\hline $\begin{array}{l}\text { Post } \\
\text { (e.g., 37-39) }\end{array}$ & $\begin{array}{l}-0.039^{* \star \star} \\
(-0.040- \\
-0.038)\end{array}$ & $\begin{array}{l}0.051^{* * *} \\
(0.050- \\
-0.052)\end{array}$ & $\begin{array}{l}0.017^{\star * *} \\
(0.016- \\
0.018)\end{array}$ & $\begin{array}{l}-0.037^{* * *} \\
(-0.038- \\
-0.037)\end{array}$ & $\begin{array}{l}0.017^{\star \star \star} \\
(0.017- \\
0.018)\end{array}$ & $\begin{array}{l}-0.003^{\text {** }} \\
(-0.003- \\
-0.002)\end{array}$ \\
\hline $\begin{array}{l}\text { Treat } \\
\text { (e.g., 1974-1976) }\end{array}$ & $\begin{array}{l}0.040^{\star \star \star} \\
(0.039- \\
0.040)\end{array}$ & $\begin{array}{l}0.087^{\star \star *} \\
(0.086- \\
0.087)\end{array}$ & $\begin{array}{l}0.061^{\star \star \star} \\
(0.06- \\
0.061)\end{array}$ & 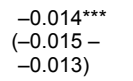 & $\begin{array}{l}0.042^{\star \star \star} \\
(0.041- \\
0.043)\end{array}$ & $\begin{array}{c}0.0007^{\star *} \\
(0.0001- \\
0.001)\end{array}$ \\
\hline$\Delta \Delta$ (Post ${ }^{\star}$ Treat $)$ & $\begin{array}{l}-0.019^{\star \star \star} \\
(-0.021- \\
-0.018)\end{array}$ & $\begin{array}{l}-0.090^{\star * \star} \\
(-0.091- \\
-0.089)\end{array}$ & $\begin{array}{c}-0.034^{\star \star \star} \\
(-0.036- \\
0.033)\end{array}$ & $\begin{array}{l}0.054^{\star \star *} \\
(0.053- \\
0.055)\end{array}$ & $\begin{array}{l}-0.027^{\star \star \star} \\
(-0.028- \\
-0.026)\end{array}$ & $\begin{array}{l}0.020^{\star \star *} \\
(0.019- \\
0.021)\end{array}$ \\
\hline Constant & $\begin{array}{l}0.282^{\star * *} \\
(0.282- \\
0.283)\end{array}$ & $\begin{array}{l}0.196^{* * *} \\
(0.195- \\
0.196)\end{array}$ & $\begin{array}{c}0.22^{* * *} \\
(0.219- \\
0.220)\end{array}$ & $\begin{array}{l}0.234^{* * *} \\
(0.233- \\
0.234)\end{array}$ & $\begin{array}{l}0.171^{\star \star *} \\
(0.0171- \\
0.172)\end{array}$ & $\begin{array}{c}0.171^{* *} \\
(0.170- \\
0.171)\end{array}$ \\
\hline \multirow[t]{4}{*}{$\mathrm{N}$} & 1,396 & 2,234 & 1,569 & 2,488 & 2,432 & 3,592 \\
\hline & \multicolumn{6}{|c|}{ Lower secondary } \\
\hline & \multicolumn{2}{|l|}{$37-39$} & \multicolumn{2}{|l|}{$38-40$} & \multicolumn{2}{|l|}{$42-44$} \\
\hline & $\Delta \Delta$ & Placebo $\Delta \boldsymbol{\Delta}$ & $\Delta \Delta$ & Placebo $\Delta \boldsymbol{\Delta}$ & $\Delta \Delta$ & Placebo $\Delta \boldsymbol{\Delta}$ \\
\hline $\begin{array}{l}\text { Post } \\
\text { (e.g., 37-39) }\end{array}$ & $\begin{array}{l}-0.029^{\star \star \star} \\
(-0.029- \\
-0.028)\end{array}$ & $\begin{array}{l}-0.047^{\star \star \star} \\
(-0.047- \\
-0.047)\end{array}$ & $\begin{array}{l}-0.012^{\star \star \star} \\
(-0.012- \\
-0.011)\end{array}$ & $\begin{array}{l}-0.038^{\star \star *} \\
(-0.038- \\
-0.037)\end{array}$ & $\begin{array}{l}-0.005^{\star \star \star} \\
(-0.006- \\
-0.005)\end{array}$ & $\begin{array}{l}-0.004^{\star \star *} \\
(-0.004- \\
-0.004)\end{array}$ \\
\hline $\begin{array}{l}\text { Treat } \\
\text { (e.g., 1974-1976) }\end{array}$ & $\begin{array}{c}-0.0001 \\
(-0.0004- \\
0.0001)\end{array}$ & $\begin{array}{c}0.016^{\star * \star} \\
(0.016- \\
0.017)\end{array}$ & $\begin{array}{c}0.004^{\star \star *} \\
(0.0035- \\
0.0041)\end{array}$ & $\begin{array}{l}0.018^{* \star *} \\
(0.017- \\
0.018)\end{array}$ & $\begin{array}{l}0.034^{\star \star \star} \\
(0.034- \\
0.035)\end{array}$ & $\begin{array}{l}0.019^{\star \star \star *} \\
(0.019- \\
0.019)\end{array}$ \\
\hline$\Delta \Delta$ (Post ${ }^{*}$ Treat $)$ & $\begin{array}{l}0.024^{\star \star \star} \\
(0.023- \\
0.024)\end{array}$ & $\begin{array}{l}0.019^{\star \star *} \\
(0.018- \\
0.019)\end{array}$ & $\begin{array}{l}0.007^{\star \star \star} \\
(0.007- \\
0.008)\end{array}$ & $\begin{array}{c}0.026^{\star * *} \\
(0.0257- \\
0.0263)\end{array}$ & $\begin{array}{c}-0.025^{\star \star \star} \\
(-0.025- \\
0.025)\end{array}$ & $\begin{array}{l}-0.0013^{\star \star *} \\
(-0.0016- \\
-0.0096)\end{array}$ \\
\hline Constant & $\begin{array}{l}0.274^{\star \star \star} \\
(0.274- \\
0.275)\end{array}$ & $\begin{array}{c}0.258^{\star \star \star} \\
(0.258- \\
0.258)\end{array}$ & $\begin{array}{l}0.257^{\star \star \star} \\
(0.257- \\
0.257)\end{array}$ & $\begin{array}{c}0.240^{\star \star \star} \\
(0.239- \\
0.240)\end{array}$ & $\begin{array}{c}0.198^{\star \star \star} \\
(0.198- \\
0.198)\end{array}$ & $\begin{array}{c}0.179^{\star \star \star} \\
(0.179- \\
0.179)\end{array}$ \\
\hline \multirow[t]{4}{*}{$\mathrm{N}$} & 16,916 & 22,038 & 18,364 & 23,466 & 23,442 & 28,038 \\
\hline & \multicolumn{6}{|c|}{ Upper secondary } \\
\hline & \multicolumn{2}{|l|}{$37-39$} & \multicolumn{2}{|l|}{$38-40$} & \multicolumn{2}{|l|}{$42-44$} \\
\hline & $\Delta \Delta$ & Placebo $\Delta \boldsymbol{\Delta}$ & $\Delta \Delta$ & Placebo $\Delta \boldsymbol{\Delta}$ & $\Delta \Delta$ & Placebo $\Delta \boldsymbol{\Delta}$ \\
\hline $\begin{array}{l}\text { Post } \\
\text { (e.g., 37-39) }\end{array}$ & $\begin{array}{l}-0.062^{\star \star *} \\
(-0.062- \\
-0.061)\end{array}$ & $\begin{array}{l}-0.098^{* * *} \\
(-0.098- \\
-0.097)\end{array}$ & $\begin{array}{l}-0.058^{\star \star \star} \\
(-0.058- \\
-0.057)\end{array}$ & $\begin{array}{l}-0.055^{\star * \star} \\
(-0.055- \\
-0.054)\end{array}$ & $\begin{array}{l}-0.015^{\star \star \star} \\
(-0.015- \\
-0.015)\end{array}$ & $\begin{array}{l}-0.019^{* * *} \\
(-0.019- \\
-0.0187)\end{array}$ \\
\hline $\begin{array}{l}\text { Treat } \\
\text { (e.g., 1974-1976) }\end{array}$ & $\begin{array}{c}0.001^{\star \star *} \\
(0.001- \\
0.002)\end{array}$ & $\begin{array}{c}0.012^{\star * *} \\
(0.012- \\
0.012)\end{array}$ & $\begin{array}{l}-0.003^{\star * *} \\
(-0.004- \\
-0.003)\end{array}$ & $\begin{array}{c}0.034^{* * *} \\
(0.034- \\
0.034)\end{array}$ & $\begin{array}{c}0.007^{* * *} \\
(0.006- \\
0.007)\end{array}$ & $\begin{array}{c}0.020^{\star * *} \\
(0.0198- \\
0.020)\end{array}$ \\
\hline$\Delta \Delta$ (Post $^{*}$ Treat $)$ & $\begin{array}{l}-0.022^{\text {***}} \\
(-0.022- \\
-0.022)\end{array}$ & $\begin{array}{c}0.036^{\star \star *} \\
(0.036- \\
0.037)\end{array}$ & $\begin{array}{l}-0.015^{\star \star \star} \\
(-0.016- \\
-0.015)\end{array}$ & $\begin{array}{l}-0.003^{* * *} \\
(-0.003- \\
-0.0025)\end{array}$ & $\begin{array}{c}0.020^{\star \star *} \\
(0.020- \\
0.021)\end{array}$ & $\begin{array}{c}0.004^{\star * *} \\
(0.0038- \\
0.0046)\end{array}$ \\
\hline Constant & $\begin{array}{c}0.367^{\star \star \star} \\
(0.367- \\
0.367)\end{array}$ & $\begin{array}{c}0.355^{\star * \star} \\
(0.355- \\
0.355)\end{array}$ & $\begin{array}{c}0.338^{\star \star *} \\
(0.338- \\
0.338)\end{array}$ & $\begin{array}{c}0.304^{\star \star *} \\
(0.304- \\
0.3045)\end{array}$ & $\begin{array}{c}0.253^{\star \star \star} \\
(0.253- \\
0.253)\end{array}$ & $\begin{array}{c}0.233^{\text {*** }} \\
(0.233- \\
0.233)\end{array}$ \\
\hline $\mathrm{N}$ & 18,443 & 19,814 & 18,503 & 19,725 & 19,095 & 20,535 \\
\hline
\end{tabular}


Table A-3: (Continued)

\begin{tabular}{|c|c|c|c|c|c|c|}
\hline & \multicolumn{6}{|c|}{ University diploma } \\
\hline & \multicolumn{2}{|l|}{$37-39$} & \multicolumn{2}{|l|}{$38-40$} & \multicolumn{2}{|l|}{$42-44$} \\
\hline & $\Delta \Delta$ & Placebo $\Delta \boldsymbol{\Delta}$ & $\Delta \Delta$ & Placebo $\Delta \boldsymbol{\Delta}$ & $\Delta \Delta$ & Placebo $\Delta \Delta$ \\
\hline $\begin{array}{l}\text { Post } \\
\text { (e.g., 37-39) }\end{array}$ & $\begin{array}{l}-0.001^{* *} \\
(-0.002- \\
-0.0003)\end{array}$ & 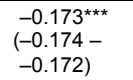 & $\begin{array}{l}-0.077^{\star \star \star} \\
(-0.078- \\
-0.076)\end{array}$ & 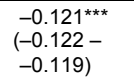 & $\begin{array}{l}-0.05^{\star \star \star} \\
(-0.052- \\
-0.050)\end{array}$ & $\begin{array}{l}0.023^{\star \star \star} \\
(0.022- \\
0.024)\end{array}$ \\
\hline $\begin{array}{l}\text { Treat } \\
\text { (e.g., 1974-1976) }\end{array}$ & 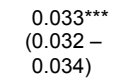 & $\begin{array}{l}-0.105^{\star \star *} \\
(-0.106- \\
-0.104)\end{array}$ & $\begin{array}{c}0.008^{\star * *} \\
(0.007- \\
0.009)\end{array}$ & $\begin{array}{l}-0.021^{* * *} \\
(-0.022- \\
-0.020)\end{array}$ & $\begin{array}{l}-0.009^{\star \star *} \\
(-0.10- \\
-0.008)\end{array}$ & $\begin{array}{l}-0.005^{\star \star \star} \\
(-0.006- \\
-0.05)\end{array}$ \\
\hline$\Delta \Delta$ (Post ${ }^{*}$ Treat $)$ & $\begin{array}{l}0.004^{* * *} \\
(0.002- \\
0.005)\end{array}$ & $\begin{array}{l}0.172^{\star \star *} \\
(0.171- \\
0.173)\end{array}$ & $\begin{array}{l}0.080^{* * *} \\
(0.078- \\
0.082)\end{array}$ & $\begin{array}{c}0.044^{* * *} \\
(0.0425- \\
0.0455)\end{array}$ & 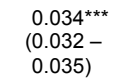 & $\begin{array}{l}-0.075^{\star \star *} \\
(-0.076- \\
-0.073)\end{array}$ \\
\hline Constant & $\begin{array}{c}0.361^{* \star *} \\
(0.361- \\
0.362)\end{array}$ & $\begin{array}{l}0.466^{* * *} \\
(0.465- \\
0.467)\end{array}$ & $\begin{array}{l}0.367^{* * *} \\
(0.366- \\
0.367)\end{array}$ & $\begin{array}{l}0.388^{\star * *} \\
(0.388- \\
0.389)\end{array}$ & $\begin{array}{l}0.283^{* * *} \\
(0.282- \\
0.284)\end{array}$ & $\begin{array}{l}0.287^{\star \star *} \\
(0.287- \\
0.288)\end{array}$ \\
\hline \multirow[t]{4}{*}{$\mathrm{N}$} & 1,306 & 1,597 & 1,344 & 1,531 & 1,283 & 1,359 \\
\hline & \multicolumn{6}{|c|}{ University degree } \\
\hline & \multicolumn{2}{|l|}{$37-39$} & \multicolumn{2}{|l|}{$38-40$} & \multicolumn{2}{|l|}{$42-44$} \\
\hline & $\Delta \Delta$ & Placebo $\Delta \mathbf{\Delta}$ & $\Delta \Delta$ & Placebo $\boldsymbol{\Delta} \boldsymbol{\Delta}$ & $\Delta \Delta$ & Placebo $\Delta \Delta$ \\
\hline $\begin{array}{l}\text { Post } \\
\text { (e.g., 37-39) }\end{array}$ & $\begin{array}{l}-0.126^{\star \star \star} \\
(-0.0129- \\
-0.125)\end{array}$ & $\begin{array}{l}-0.142^{\star \star \star} \\
(-0.143- \\
-0.142)\end{array}$ & $\begin{array}{l}-0.090^{\star \star \star} \\
(-0.090- \\
-0.089)\end{array}$ & $\begin{array}{l}-0.092^{\star \star \star} \\
(-0.09- \\
-0.091)\end{array}$ & $\begin{array}{l}-0.024^{\star * *} \\
(-0.024- \\
-0.023)\end{array}$ & $\begin{array}{l}-0.048^{\star \star *} \\
(-0.049- \\
-0.048)\end{array}$ \\
\hline $\begin{array}{l}\text { Treat } \\
\text { (e.g., 1974-1976) }\end{array}$ & $\begin{array}{l}0.014^{* * *} \\
(0.014- \\
0.015)\end{array}$ & $\begin{array}{l}0.022^{\star * *} \\
(0.011- \\
0.012)\end{array}$ & $\begin{array}{l}0.033^{* * *} \\
(0.033- \\
0.034)\end{array}$ & $\begin{array}{l}0.003^{* * *} \\
(0.003- \\
0.004)\end{array}$ & $\begin{array}{l}0.005^{\star * *} \\
(0.005- \\
0.006)\end{array}$ & $\begin{array}{l}-0.006^{* * *} \\
(-0.007- \\
-0.006)\end{array}$ \\
\hline$\Delta \Delta$ (Post $^{*}$ Treat $)$ & $\begin{array}{l}-0.005^{\star \star \star} \\
(-0.006- \\
-0.005)\end{array}$ & $\begin{array}{l}0.017^{\star * *} \\
(0.016- \\
0.017)\end{array}$ & 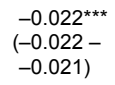 & $\begin{array}{l}0.002^{\star \star *} \\
(0.0015- \\
0.003)\end{array}$ & $\begin{array}{l}-0.028^{* * *} \\
(-0.029- \\
-0.028)\end{array}$ & $\begin{array}{l}0.024^{\star \star *} \\
(0.023- \\
0.025)\end{array}$ \\
\hline Constant & $\begin{array}{c}0.492^{\star \star \star} \\
(0.491- \\
0.492)\end{array}$ & $\begin{array}{l}0.480^{\star \star *} \\
(0.480- \\
0.481)\end{array}$ & 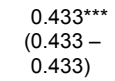 & $\begin{array}{c}0.430^{\star \star *} \\
(0.430- \\
0.430)\end{array}$ & $\begin{array}{c}0.332^{\star \star *} \\
(0.331- \\
0.332)\end{array}$ & $\begin{array}{c}0.338^{\star \star \star} \\
(0.337- \\
0.338)\end{array}$ \\
\hline $\mathrm{N}$ & 8,676 & 8,196 & 8,620 & 7,920 & 7,366 & 6,573 \\
\hline
\end{tabular}

Source: Elaboration of the authors based on the Italian Labor Force Survey (LFS) data 2004-2014 accessed through the Laboratorio per l'Analisi dei Dati ELEmentari (ADELE) of Istat in Florence.

Note: ${ }^{\star} p \leq 0.05,{ }^{\star \star} p \leq 0.01,{ }^{* \star *} p \leq 0.001$. Robust $95 \%$ confidence intervals in parentheses. 
Caltabiano, Comolli \& Rosina: The effect of the Great Recession on permanent childlessness in Italy 